\title{
Brecht eu misturo com Caetano citação, mercado e forma musical
}

Nicholas Brown ${ }^{1}$

Resumo

Este ensaio demostra que há uma afinidade metodológica profunda entre a prática musical de Caetano Veloso a partir de 1969 e a dos esforços colaborativos de Bertolt Brecht e Kurt Weill de 1928 a 1930. Sem dúvida, muito há que as separe, do ponto de vista ideológico, histórico, e estético. Porém as diferenças históricas são postas em relevo pela identidade metodológica; as diferenças ideológicas assumem novas valências à sua luz; e as diferenças estéticas definem as possibilidades e os limites do sentido musical em nosso próprio tempo.

\section{Palavras-chave}

Bertolt Brecht, Kurt Weill, Caetano Veloso, mercadoria, forma musical.

Recebido em 17 de dezembro de 2013

Aprovado em 30 de maio de 2014

BROWN, Nicholas. Brecht eu misturo com Caetano: citação, mercado e forma musical. Revista do Instituto de Estudos Brasileiros, Brasil, n. 59, p. 149-190, dez. 2014.

D0I: http://dx.doi.org/10.11606/issn.2316-901X.v0i59p149-190

1 Universidade de Illinois (UIC, Chicago, Illinois, EUA). 


\title{
Bertolt Brecht, Kurt Weill and \\ Caetano Veloso \\ Citation, Market and Musical Form
}

\section{Nicholas Brown}

\begin{abstract}
This essay asserts a profound methodological affinity between Caetano Veloso's musical practice since 1969 and that of Bertolt Brecht and Kurt Weill's collaborative efforts from 1928 to 1930. No doubt a great deal - ideological, historical, and aesthetic - separates them as well. The historical differences are, however, brought into relief by their methodological identity; the ideological differences assume new valences in its light; and the aesthetic differences define the possibilities and limits of musical meaning in our own time.
\end{abstract}

Keywords

Bertolt Brecht, Kurt Weill, Caetano Veloso, commodity, musical form 


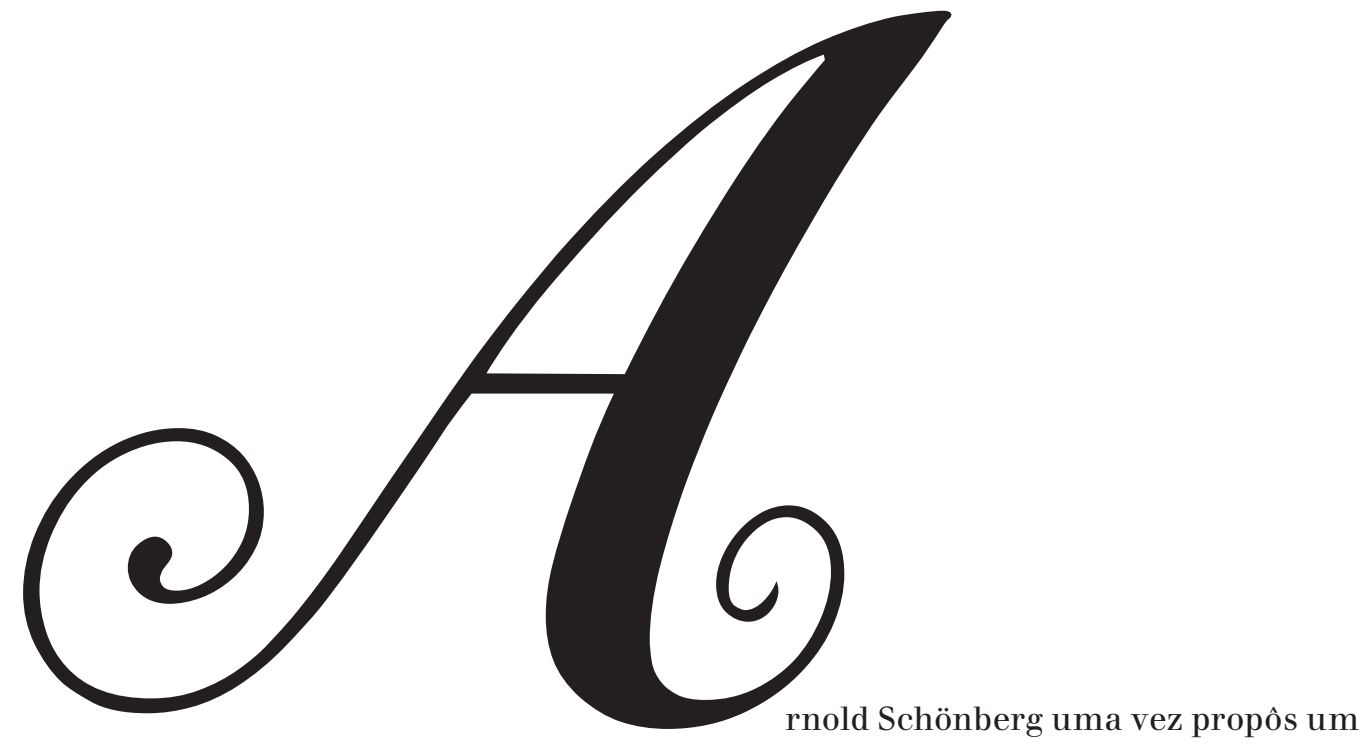
simples critério: "se é arte, não é para todos; e se é para todos, não é arte". ${ }^{2}$ A colocação é evidentemente elitista, mas não é evidentemente falsa. Não há nenhuma razão para que ela seja verdadeira em todos os momentos: de fato, "arte para todos" pode ser um corolário indispensável de qualquer impulso que seja genuinamente revolucionário. Mas em sociedades de mercado como a nossa - em sociedades nas quais um objeto cultural pode ser "para todos", quando passa pelo mercado, ou seja, ao se tornar uma mercadoria, e, assim, ao ser uma mercadoria desde a sua concepção -, não é totalmente certo que uma mercadoria artística possa ser, ao mesmo tempo, uma obra de arte. Marx entendia que as mercadorias, apesar de quase universais, constituem uma classe distinta de objetos cujas finalidades se encontram fora de si mesmos: qualquer conteúdo material que uma mercadoria possa aparentar ter (o conteúdo concreto de um martelo parecer ser, por exemplo, a capacidade de martelar), o seu conteúdo essencial, em uma sociedade de mercado, é o ato da troca para o qual é produzido ${ }^{3}$. Um martelo certamente significa "martelar" para o seu comprador - ou talvez signifique "um bom presente de aniversário", "um

2 SCHÖNBERG, Arnold. Neue Musik, veraltete Musik, Stil und Gedanke. In: Stil und Gedanke: Aufsätze zur Musik. Frankfurt am Main: Fischer, 1976, p. 34 .

3 A lógica é, com certeza, melhor desenvolvida no segundo capítulo do primeiro volume do Capital de Marx. Para um melhor entendimento da lógica aplicada a obras de arte, ver BROWN, Nicholas. The Work of Art in the Aage of its Real Subsumption Under Capital. Nonsite. Disponível em: <http://nonsite.org/editorial/ the-work-of-art-in-the-age-of-its-real-subsumption-under-capital>. Uma versão em português sairá em uma futura edição do Centro de Estudos Marxistas (CEMARX). 
bom e pesado peso de papel", "uma arma" ou "uma excelente obra de design industrial" -, mas não para o seu vendedor, para quem não significa nada além de dinheiro. Mas o conceito de obra de arte está ligado, igualmente em suas acepções cotidianas e esotéricas, a um conjunto de regras fundamentais que lhe são internas; ou seja, simplesmente, à produção de um significado - além do fato externo da permutabilidade - que não depende da atitude de um comprador. Uma maneira de se entender o modernismo, em qualquer período, é através do imperativo, ao mesmo tempo idológico e real, de evitar a determinação do mercado: mas somente ao custo de se abandonar o imperativo de ser "para todos". Entendida como normativa, então, a máxima de Schönberg incorpora a arrogância insuportável do modernismo; entendida como indicativa, ela surge como resultado do seu dilema insuperável.

De vez em quando, contudo, artistas preferem confrontar o dilema ao invés de evitá-lo: correr o risco de um mercado anônimo de bens culturais ao invés de submeter a produção estética ao mercado ou isolá-la do contato direto com ele. Mas tal confronto não pode parar no simples imperativo de ser "para todos", o que, em uma sociedade de mercado, como vimos acima, implica, qualquer que seja a atividade subjetiva do artista, um ajustamento da obra ao mercado que desvirtua, imediatamente, sua pretensão de ser uma obra de arte de fato. Este ensaio defende que Caetano Veloso, em 1969, e Bertolt Brecht e Kurt Weill, em 1928, desenvolveram conjuntos, notavelmente similares, de procedimentos estéticos para a produção de significados artísticos - ou seja, para produzir obras - mesmo dentro do campo de mercadorias culturais, que tem como característica anular qualquer significado. Embora exista uma plausível relação genética entre Brecht e Caetano - a apropriação brasileira da dramarturgia brechtiana assinala fortemente o meio estético do qual Caetano emerge - este ensaio não está preocupado com a gênese histórica nesse sentido; a afirmação, pelo contrário, é a de que cada artista produz uma forte resposta, em circustâncias históricas que são diferentes mas não estranhas entre si, para o duplo imperativo de se produzir obras que sejam, ao mesmo tempo, arte e para todos. Da mesma forma, aqui não há qualquer consideração sobre o legado genético desses dois momentos estético-históricos. De fato, em um contexto contemporâneo norte-americano, os músicos Jack White e Cee-Lo Green - tão diferentes um do outro em termos musicais quanto em relação ao que se expõe neste ensaio - estão, todavia, operando nos mesmos moldes processuais como Brecht e Caetano, mas em provável desconhecimento de ambos. Em vez disso, a questão é a relação entre esse duplo imperativo, de um lado, e, do outro, a história - pela qual se entende o 
desenvolvimento do capitalismo, que é desigual entre os setores, bem como entre as zonas geográficas. Brecht e Weill estão trabalhando nesse problema em um tempo e espaço nos quais os procedimentos nãomercantis estão prontamente disponíveis e devem ser expressamente rejeitados; as maiores inovações de Caetano vêm em um momento em que a possibilidade de tais procedimentos é por ele entendida como negada; e White e Green (que não podem ser discutidos em maiores detalhes no espaço deste estudo) estão trabalhando em condições nas quais tais procedimentos não são mais que uma memória distante. A questão da relevância, para o presente momento, do enfoque brechtiano/weilliano/ velosiano delineado no que se segue, é outra questão. Quando a saturação total da sociedade pelos mercados é, ao mesmo tempo, a ideologia e o programa da hegemonia neoliberal contemporânea, a questão de como circular valores que não podem ser reduzidos para a troca é urgente e não somente para os artistas. Mas antes de voltarmos nossa atenção para os procedimentos e as obras em questão, é preciso fazer um desvio através de Hegel, em cujo sistema a posição instável da música revela a suscetibilidade peculiar dessa última aos problemas da heteronomia do mercado.

Como Hegel inicia em sua discussão sobre a música, ele admite estranhamente que é "pouco versado nessa área e deve, portanto, pedir desculpas antecipadamente". ${ }^{4}$ A perplexidade de Hegel tem dois objetivos, e apenas parte pode ser atribuída à sua relativa ignorância em música e à falta de um gosto musical avançado. Primeiramente, Hegel se aproxima do limiar conceitual do significado imanente do meio, mas não o atravessa. Em sua discussão sobre pintura, Hegel, por vezes, chega ao ponto de manter indiferente o conteúdo referencial, enfatizando a forma e a técnica como a substância de uma obra ${ }^{5}$. Mas, quando a música "recua em seu próprio meio", Hegel não vê nada além de um trabalho de detalhes, "somente uma questão para especialistas e connoisseurs". ${ }^{6}$ Hegel, mesmo que se aproxime do limiar de um conteúdo que deveria pertencer exclusivamente a operações dentro de uma forma ou meio, não possui um conceito de uma ideia puramente musical ou plástica ${ }^{7}$. De um

4 HEGEL, G.W.F. Vorlesungen über die Ästhetik III. Frankfurt am Main: Suhrkamp, 1986, p. 137 .

5 Ver HEGEL, Ästhetik III, p. 36-7.

6 HEGEL, Ästhetik III, p. 145.

7 Mais precisamente, e mais escandalosamente, a música enquanto tema, para Hegel, não é uma ideia a ser desenvolvida, mas sim uma mera sequência que se esgota na primeira afirmação. Ver Ästhetik III, p. 142. O escândalo é que Hegel era um contemporâneo de Beethoven. 
lado desse limiar, Hegel parece presciente e esteticamente arriscado; por outro, bitolado e provinciano. O modelo de Hegel não se limita à Estética.

Mas essa é somente a primeira perplexidade de Hegel. A segunda é que a música, como ele então entende, não tem lugar em seu sistema. Desde que possa ser atrelada a um significado não-musical, a música só fica em segundo lugar, seguindo a poesia e sua habilidade de registrar a interioridade do pensamento, e, de fato, essa penúltima posição é o lugar onde ela se mantém oficialmente no sistema de Hegel. Mas, nesse caso, a música é reduzida para fornecer efeitos amplificadores de um conteúdo já existente. Alternativamente, a música pode, em vez de expressar uma ideia, "provocar" ideias em nós enquanto ouvintes; mas, nesse caso, a ideia é meramente "nossa" e não pertence à obra ${ }^{8}$. Por último, a música pode afetar diretamente nossos estados mentais, ultrapassando por completo a ideação: a música pode "penetrar", "aproveitar", "tocar", “desenhar", “colocar em movimento", "inflamar", "levar embora”, "divertir", “distrair", "estimular", "incitar” (eindringen, fassen, berühren, fortziehen, in Bewegung setzen, anfeuern, heben, beschäftigen, abziehen, antreiben, zum Angriff anfeuern) e assim por diante 9 . Mas estados afetivos são, eles mesmos, simples e abstratos, e não possuem qualquer conteúdo próprio. O significado somente pode ser oferecido por um suplemento não-musical; quer se trate de uma balada ou de um contexto de fervor nacionalista. Na verdade, em uma análise minunciosa, as duas primeiras possibilidades hegelianas revelam-se somente como versões de uma terceira: se a música "provoca" ideias que não estão na própia música ou amplifica as ideias que são complementares a ela, elas são formas de induzir um estado em vez de produzir um significado. Como Hegel não tem um conceito de uma ideia puramente musical, a possibilidade restante (quarta possibilidade), a música que permanence “dentro dos domínios puramente musicais dos sons", assinala o estado fundamental da música como tal, o que "não é estritamente contado entre as artes". ${ }^{10}$

Não somos obrigados a nos interessar sobre a questão do lugar ao qual a música pertence no sistema das artes de Hegel. Mas a perplexidade de Hegel aponta para um problema que é urgente para nós hoje, quando a música popular - que significa música comercial no final do século $\mathrm{XX}$ e no início do XXI - é, quando não simplesmente decorativa, dada quase que inteiramente para amplificar o conteúdo pré-fabricado ou para

\footnotetext{
8 HEGEL, Ästhetik III, p. 146.

9 HEGEL, Ästhetik III, p. 157, p. 158.

10 HEGEL, Ästhetik III, p. 14,8, p. 149.
} 
produzir efeitos que passam despercebidos totalmente pelo conteúdo. A dificuldade de Hegel é que a característica específica que distingue a música das outras artes é a sua habilidade de produzir estados afetivos nos ouvintes. Esse aspecto da diferença específica da música, em relação às outras artes, é a diferença da poesia que permitiu (alguma) música na República de Platão; para Aristóteles, era um lugar-comum pelo qual ele não via necessidade de disputa ${ }^{11}$. Para tomar somente o elemento mais básico, qualquer batida musical percebida seria suficiente para organizar os movimentos internos ou externos de um ouvinte. Nas palavras de Hegel, "desde que o tempo do som é também o tempo do sujeito, o som (...) coloca o eu em movimento". ${ }^{12}$ Nossos neurocientistas contemporâneos chamam isso de "tempo entrainment". ${ }^{13}$ Mas, como veremos em breve, essa característica parece desqualificar a música das outras artes ainda mais fortemente hoje em dia do que em Hegel.

Em sua discussão em torno de Laocoonte, G. E. Lessing estava exasperado com a crítica que pudesse pular para conclusões interpretativas sem passar pelo momento da determinação imanente do meio. "Quando eu examino as razões que citei para explicar o motivo pelo qual o escultor de Laocoonte é tão comedido na expressão da dor no corpo", ele diz, "creio que elas derivam, sem exceção, das condições específicas da arte, dos limites necessários e das exigências impostas pela escultura. Não posso imaginar aplicar qualquer uma delas para a poesia". ${ }^{14}$ Não é que o grego fosse, como diz Winkelmann, "mesmo nas extermidades,

11 PLATÃO. The Republic, Livro III 398-403, especialmente, 401d; ARISTÓTELES, Politics, Livro VIII, Capítulo V, 1340a, 1340b.

12 HEGEL, Ästhetik III, p. 146-7.

13 Há uma robusta literatura sobre "tempo entrainment." Ver NOZORADAN, Sylvie; PERETZ, Isabelle; e MOURAUX, André. Selective neuronal entrainment to the beat and meter embedded in a musical rhythm. Journal of Neuroscience n. 32, p. 17572-81, 2012. DOI: 10.1523/JNEUROSCI.3203-12.2012. É claro que os estudos neurocientíficos sobre as artes não se limitam aos efeitos da música. Ver, por exemplo, GOLDMAN, Alvin. Imagination and simulation in audience response to fiction. In: NICHOLS, Shaun (org.). The Architecture of the Imagination. London: Oxford, 2006, p. 41-56. Mas enquanto os efeitos neurológicos da representação literal não incluem o ato crucial da interpretação e, portanto, claramente não são responsáveis por uma característica-chave da literatura, os efeitos da música no corpo, os quais a ciência neural pode, eventualmente, ser equipada para entender, parecem constituir intuitivamente a própria existência da música. É fácil, conceitualmente, subordinar, juntamente com Brecht, a "empatia coagida" (um efeito cuja reflexão na literatura é parte do projeto de Goldman) ao significado literal (que não é parte do projeto de Goldman). Com a música, é menos óbvio que os efeitos provocados possam ser subordinados.

14. LESSING, Gotthold Ephraim. Laokoon: Oder, Über die Grenzen der Malerei und Poesie. Stuttgart: Reclam, 2012, p. 28. 
uma grande e firme alma" em comparação às vítimas do moderno, mas que o escultor de Laocoonte teve que lidar com a dificuldade de fazer, entre outras coisas, uma grande cavidade em sua escultura que um grito convincente exige ${ }^{15}$. Hoje a percepção de Lessing deve ser levada um passo a frente: o conceito do meio ou suporte material deve ser expandido para incluir o modo de distribuição, que impõe limites e determina possibilidades com tanta força quanto o próprio suporte material.

Agora, o que a música faz por excelência - provocar estados afetivos nos ouvintes - parece definitivamente encerrar, nas condições atuais, a possibilidade dela ser um meio para obras de arte. Pois qualquer efeito provocado, nas condições atuais, já é sempre uma mercadoria. Como Roberto Schwarz coloca de forma concisa: "Em regime capitalista, basta uma forma de utilidade qualquer para que algo ou alguém sejam candidatos a 'membro de pleno direito no mundo das mercadorias' (K. Marx, Das Kapital, vol. II, cap. 20, VIII)". ${ }^{16}$ Agora, só porque uma obra de arte é uma mercadoria, ela não é somente ou imediatamente uma mercadoria. Entre outras possibilidades, o caráter mercantil de uma obra de arte pode ser contido por meio do estabelecimento de um campo de produção restrita, conceito defendido por Bourdieu, que forçosamente substitui os "vereditos imprevisíveis de um público anônimo" - o problema de um vendedor - por um "público de iguais que também são concorrentes". ${ }^{17}$ Dessa forma, o modernismo, em sua forma paradigmática, podia afirmar a autonomia de obras de arte dentro de uma plena sociedade da mercadoria. Mas a especificidade do momento atual é que o momento anterior foi substituído: os campos restritos - "especialistas e conhecedores" de Hegel - foram superados de uma vez por todas pelo mercado anônimo, e, doravante, todas as obras de arte logo são, afinal, mercadorias. Isso, a rigor, não precisa ser verdade para que funcione como a ideologia estética dominante em nosso momento atual. Indubitavelmente, esferas restritas, dos ambientes amadores aos de vanguarda, ainda existem aqui e ali, mas a sua extinção é tida como certa por todas as partes: esferas restritas são justificadas não por sua autonomia em relação ao mercado em geral, mas por sua contribuição a ele. Atualmente, qualquer produção estética que se imagina imune a essa dinâmica - ao contrário de procurar meios de superá-la, o que é outra questão - escolhe uma ingenuidade imperdoável.

15 Apud LESSING, p. 10.

I6 SCHWARZ, Roberto. Tribulação de um pai de família. In: O pai de família e outros estudos. $2^{\mathrm{a}}$ ed. Rio de Janeiro: Paz e Terra, 1992, p. 24, nota de rodapé 1.

17 BOURDIEU, Pierre. Le marché des biens symboliques. L'Anée sociologique n. 22, p. 54 e 56,1971 . 
Hoje, o significado das obras musicais não pode ser estabelecido sem que levemos em consideração explicitamente o seu modo de distribuição, ou seja, sem considerarmos o fato de que elas são entendidas como imediatamente mercadorias. E, em tal situação, é inevitável o fato de que, nas palavras de Roberto Schwarz, "as formas concretas de atividade deixam de ter em si mesmas a sua razão de ser; a sua finalidade lhes é externa, a sua forma particular é inessencial". ${ }^{18}$ A finalidade essencial da mercadoria é encontrar quem a compre no mercado anônimo; qualquer outro fim, o potencial valor de uso, não é importante: de fato, é deixada ao consumidor a decisão sobre o que a mercadoria é ou se ela tem algum valor. Em outras palavras, nenhuma mercadoria pode plausivelmente produzir um significado - cuja finalidade é, por definição, essencial - e nenhum efeito subjetivo da música, sob essas condições, deixa de ser uma mercadoria. Mas um artefato deve produzir um sentido - quer seja referencial, puramente imanente do meio, ou não - a fim de qualificarse como uma obra de arte $^{19}$. Isso leva à consequência infeliz de que a música da qual alguém gosta seja, na medida em que as suas finalidades estão vinculadas aos efeitos pelos quais alguém dela gosta, excluída do sistema de arte. Portanto, é urgente a questão de como produzir música cuja essência não reside nos efeitos que ela produz.

As colaborações de Bertolt Brecht e Kurt Weill compõe o nosso primeiro estudo de caso. Quase quarenta anos depois de Theodor Adorno ter proferido o que parece ser um golpe mortal às reivindicações mais atraentes de Brecht, Roberto Schwarz foi bastante audacioso ao retornar a uma questão bastante básica: como Bertolt Brecht quer dizer o que diz ${ }^{20}$ ? O problema é precisamente o da autonomia, ou da sua falta, enquanto no ensaio de Adorno sobre a questão trata-se do problema do "engajamento", ou da heteronomia da arte em relação à política ${ }^{21}$. Como se sabe, o teatro brechtiano visa explicitamente a uma diferente autonomia, isto é, a uma autonomia em relação ao mercado. $\mathrm{O}$ entretenimento, por certo, precede

18 SCHWARZ, Roberto, Tribulação de um pai de família, p. 24.

19 Esse último postulado não é necessário nos estudos sociológicos, antropológicos, religiosos, entre outros, que podem tratar como indiferentes as diferenças entre arte e um papel de parede, a vida cotidiana ou a prática religiosa. Mas, sem ele, o estudo da cultura, como conhecemos, é incoerente.

20 SCHWARZ, Roberto. Altos e baixos da atualidade de Brecht. In: Sequências brasileiras: ensaios. São Paulo: Companhia das Letras, 1999, p. 113-148.

21 ADORNO, Theodor W. Engagement. Noten zur Literature. Frankfurt: Suhrkamp, 2003, p. 409-430. Como o título em alemão deixa claro, a terminologia é de Sarte e não de Adorno. Após discutir o ensaio de Adorno com Iná Camargo Costa, sou forçado a admitir um certo elemento de má-fé no argumento de Adorno. Contudo, não creio que isso desqualifique a sua crítica específica. 
ao mercado: a ópera "era um modo de diversão muito antes de ser uma mercadoria". ${ }^{22}$ Mas, sob as condições atuais, "a arte é uma mercadoria" cujo valor advém, no caso da ópera, da "função social do aparato teatral, qual seja, a de promover o entretenimento". ${ }^{23}$ Em Mahagonny, esse modo de diversão é artisticamente neutralizado ao ser estruturado:

No que diz respeito a [Mahagonny], seu tema é a diversão: diversão não apenas como forma, mas como questão subjetiva. A diversão é algo para ser, no mínimo, objeto de indagação, mesmo se a indagação for um objeto de diversão. A diversão entra aqui em sua forma histórica presente: como uma mercadoria. ${ }^{24}$

As duas partes do quiasmo não são simétricas: a indagação como objeto de diversão (Mahagonny) é uma mercadoria; já a diversão como um objeto de indagação (Mahagonny) não o é. Apoiado pelo aparato teatral, o teatro épico permanece o mesmo, porém dentro de um “corpo estrangeiro". ${ }^{25}$ Entretanto, a autonomia de mercado é entendida como heteronômica. O objetivo do teatro épico é "desenvolver um objeto de instrução fora dos meios de entretenimento, e converter certas instituições de entretenimento em órgãos de publicidade". ${ }^{26}$ Mesmo que o processo seja mantido, Brecht torna a antiga defesa da poesia - "ensinar e deleitar" - mais fundamentalmente em uma escolha de prioridades: "Vergnügungstheater oder Lehrtheater?" (Teatro para a diversão ou teatro para o aprendizado? $)^{27}$.

Adorno levanta uma objeção, muito básica em sua essência e que retorna à crítica de Hegel, a essa orientação, na introdução às suas conferências sobre estética, sobre a possibilidade de defender a arte por meio de seus fins. De uma perspectiva mais abstrata, a escolha que Brecht impõe não é uma escolha em absoluto: ambos os teatros, para a diversão e para o aprendizado, são teatros para algo, ou seja, ambos devem ser julgados por sua eficácia como meios para outros fins. Se a obra de arte não deve "ter seu fim e seu objetivo em si mesma", mas deve, por outro lado, ser avaliada como um meio para um fim outro, então o foco de

22 BRECHT, Bertolt. Das moderne Theater ist das epische Theater. In: Schriften zum Theater. Berlin: Suhrkamp, 1957, p. 16. 
julgamento adequado muda da obra de arte para, ao mesmo tempo, o fim ao qual ela alega servir e para a eficácia de seu status como um meio ${ }^{28}$. Para a crítica de Hegel, não importa se os fins pretendidos são elevados ou vulgares: sua lista improvisada nomeia "instrução, purificação, progresso, ganho financeiro, batalha por fama e honra". Mais tarde, Hegel acrescentará "passatempos e diversões superficiais" e "agitação política" como extras ${ }^{29}$. A questão é que nenhum dos momentos - o do status da obra de arte como um meio (essencial ou arbitrário?) e o do status dos fins para os quais a arte se subordina (desejáveis ou indesejáveis?) - são autoevidentes. Isso se aplica também aos atuais traficantes de empatia, aos modeladores de subjetividade de araque, aos benfeitores comunitários e aos guardiões da civilidade, da mesma forma que se aplicava ao teatro radical de outrora.

No início da década de 1950, Adorno suspeita dos fins com os quais Brecht está engajado. De modo mais devastador, Adorno aponta para a implausibilidade da obra de arte como um meio. Para colocar em prática o que se pretende - "atingir, por meio de imagens, o âmago do capitalismo" -, o teatro brechtiano recorreu aos aparatos técnicos disponíveis ao drama como meio ${ }^{30}$. Mas, sob a perspectiva da verdade proposicional, da doutrina revolucionária que a obra de arte deve conter, esses aparatos técnicos são distorções, e aqui Adorno não apenas discorda de Brecht, mas demonstra Brecht necessariamente discordando de si mesmo. Em A Santa Joana dos Matadouros, por exemplo, Brecht de fato requer um certo nível de coincidência ao condensar todo um conjunto de contradições sobre a figura de Joana. Mas, “que uma liderança de greve apoiada por um partido devesse confiar uma tarefa decisiva a um não-membro é, mesmo com a maior quantidade possível de licença poética, algo tão impensável quanto a ideia de que, pelo fracasso daquele indivíduo, toda a greve fracassaria". ${ }^{31}$ A questão aqui não é a de que Brecht deveria ter escrito um tratado sobre a ação revolucionária em vez de uma peça, mas a de que uma peça não pode ser, ao mesmo tempo, um tratado sobre a ação revolucionária - ou não pode ser uma boa peça. De fato, a própria necessidade de que Santa Joana seja uma peça falsifica o tratado que ela também afirma ser. A ostensiva tese presente na peça - que promover atos individuais de bondade é um substituto compensatório para a ação

28 HEGEL, G.W.F. Vorlesungen über die Ästhetik I. Berlin: Suhrkamp, 1986, p. 82.

29 HEGEL, Ästhetik I, p. 82; HEGEL, Ästhetik III, p. 269.

zo ADORNO, Theodor W. Engagement. Noten zur Literatur. Frankfurt: Suhrkamp, 2003 , p. 4,16.

31 ADORNO, Theodor W. Engagement. Noten zur Literatur. Frankfurt: Suhrkamp, 2003 , p. 4,17. 
coletiva - é subvertida pelo fato de que tudo depende, necessariamente, pois se trata de uma peça, do sucesso ou fracasso dos atos individuais de bondade realizados por Joana. Em vez disso, como é de se esperar, bruscamente refutando as reivindicações de Brecht, Adorno desdobra-as delicadamente sobre aquilo ao qual procuram se opor, efetivamente alinhando a dramaturgia de Brecht ao esteticismo formal, pois o próximo movimento consiste em insistir que o didatismo de Brecht é, na verdade, mais um princípio formal do que um princípio político. "A técnica reducionista de Brecht seria legítima apenas no campo da 'arte pela arte', o qual sua versão de engajamento condena, como o faz Luculo". ${ }^{32}$

O brilhantismo da intervenção posterior de Schwarz reside em observar que essa crítica é devastadora à reivindicação de Brecht por uma eficácia didática, mas não à peça à qual essa reivindicação é feita. A perda não é tão grande quanto pode parecer, afinal, lembra Schwarz, as "lições" brechtianas são "de alcance modesto", e não é óbvio que elas permaneçam hoje à frente dos desenvolvimentos históricos ${ }^{33}$. "Assim, diversamente do proclamado, a verdade nas peças não estaria nos ensinamentos transmitidos, nos teoremas sobre a luta de classes, mas na dinâmica objetiva do conjunto (...)". ${ }^{34}$ Isso não quer dizer que as peças do dramaturgo não tenham conteúdo cognitivo ou força política, mas sim que seus conteúdos e políticas são mediados pela natureza auto-legisladora da obra autônoma. Como corolário, quando a obra titubeia enquanto obra, como ocorre no terceiro ato de Mãe Coragem e seus filhos, os conteúdos e políticas ostensivos presentes na peça se dispersam ao vento, como tantas outras boas intenções.

A releitura reveladora de $A$ Santa Joana dos Matadouros empreendida por Schwarz, que de fato traz à tona essa dinâmica objetiva, merece atenção cuidadosa por si só, mas um aspecto é aqui particularmente importante. "Confiando em seu talento excepcional para o pastiche, [Brecht] apresentou as vicissitudes da luta de classe e as maquinações do cartel dos produtos enlatados [...] em versos que imitam Schiller, Hölderlin, o segundo Fausto, a poesia expressionista ou as tragédias gregas (percebidas como alemãs por honoris causa)". Em A canção do destino de Hyperion, de Hölderlin, por exemplo, a qual Schwarz destaca como fulcral para o sistema de citação da peça, o destino humano é figurativizado como errância heroica: vagar sem consolo, "Como água do

32 ADORNO, Theodor W. Engagement. Noten zur Literatur. Frankfurt: Suhrkamp, 2003, p. 419

33 SCHWARZ, Roberto. Altos e baixos da atualidade de Brecht, p. 133.

34. SCHWARZ, Roberto. Altos e baixos da atualidade de Brecht, p. 133. 
penhasco / pelo penhasco arremessada". Em Santa Joana, são os preços das ações em declínio que são "Lançadas como água, de penhasco em penhasco". ${ }^{35}$

Em seus contornos mais simples, o pastiche modernista, enquanto comentário recíproco entre o passado heroico e o presente prosaico, dificilmente se renova com Brecht. Em termos de virtuosismo ostensivo, o episódio dos "Touros do sol”, em Ulisses, já tinha desenvolvido essa modalidade de modo bem mais aprofundado do que Brecht. Porém, a diferença brechtiana é profunda, perpassando em Schwarz o rótulo circunspecto de "a atualidade do conjunto", ${ }^{36}$ outrora conhecido como História, ou o que, em termos mais abstratos, corresponde à "identidade da identidade e diferença" hegeliana. Em outras palavras, o peculiar da fisgada brechtiana não reside na diferença entre a fonte clássica e o material moderno, mas em sua identidade, que não está apenas no projeto do artista. A brutalidade mesquinha do homem de negócios é o ponto final da batalha romântica, não a sua negação: "algo [do rei dos frigoríficos] Bocarra já existia no Fausto". ${ }^{37}$

Mas não há lição nessa identidade. Não há final exterior ao qual a imagem dramática está subordinada. Em vez disso, os dois momentos de Fausto e Bocarra estão postulados como uma identidade na imagem dramática, e isso é tudo. O que é apresentado não é uma doutrina, mas sim uma figura: Fausto como Bocarra, uma ideia poética (a qual é também, como se verá, uma ideia narrativa). Dessa figura, nada aprendemos sobre o modo como o capitalismo funciona. Ao contrário, Brecht abre uma linha de questionamento por meio de uma configuração sensorial. A ideia brechtiana é uma questão de postular conteúdos disponíveis de um modo particular: uma ação familiar (digamos) como produto de motivos que se alternam em vez de natureza humana; ou brutalidade burguesa como algo contíguo à revolução burguesa.

Em uma série de listas conhecidas, Brecht contrasta forma tradicional (dramatische) e forma épica (epische) ${ }^{38}$. Algumas das categorias são primordialmente formais (a sequência dos eventos é linear ou curvilínea?), enquanto outras são mais obviamente ideológicas (as pessoas são imutáveis ou são mutáveis e estão mudando?). Mas os engajamentos

35 BRECHT, Bertolt. Die heilige Johanna der Schlachthöfe. Werke, vol. 3, p. 211. A observação é extraída de SCHWARZ, Altos e baixos da atualidade de Brecht, ensaio que articula, em leitura atenta, A canção do destino de Hyperion e A Santa Joana dos Matadouros.

36 SCHWARZ, Roberto. Altos e baixos da atualidade de Brecht, p. 14,1.

37 SCHWARZ, Roberto. Altos e baixos da atualidade de Brecht, p. 148.

38 BRECHT, Bertolt. Das moderne Theater ist das epische Theater, p. 19-22. 
ideológicos, que são de fato cruciais, não podem ser considerados lições. Mesmo se a ideia do épico - digamos, "a natureza humana não é dada" - pudesse ser demonstrada como correta, tudo que uma peça pode demonstrar é sua plausibilidade: uma categoria aristotélica, não uma categoria particularmente brechtiana, a qual o dramaturgo preserva de modo enciumado emoldurando sua própria implausibilidade como implausível. Santa Joana obteve sucesso precisamente porque não rompe fundamentalmente com as normas da arte herdadas dos primeiros românticos. A peça critica essas normas, não há dúvida, mas o faz como poesia: de fato, a obra satisfaz enfaticamente a exigência de Friedrich Schlegel de que toda crítica de poesia seja, ela mesma, "poesia em todos os aspectos e, igualmente, uma obra de arte viva e vibrante". ${ }^{39}$

Nada disso, e isso é um ponto a se enfatizar, embota o viés materialista da crítica de Brecht. O sentido é produzido por meio de uma crítica de poesia que também é poética, mas isso não significa que o sentido fica restrito ao campo da poesia. O sentido é profundamente compatível com o conjunto de lições possíveis de serem extraídas, lições as quais Brecht está impedido de apresentar sem distorção incapacitante resultante das limitações da forma. A crítica de Brecht a Hölderlin e Goethe está alinhada à crítica de Marx a Hegel ou mesmo à crítica de Adorno a Heidegger: ao introduzir conteúdo concreto novamente em uma linguagem abstrata, Brecht postula uma identidade entre o vulgar, o conteúdo social do dia a dia e o pensamento sublime e abstrato. O sublime risco existencial de um mundo universalmente sem garantias se torna o risco de perder dinheiro. (Para outros, seu ponto final, o "Desconhecido" na canção de Hölderlin, é simplesmente o desemprego). A ideia poética de Brecht - a manipulação mesquinha do mercado financeiro (mesquinha em suas motivações e nos danos que causa) narrada na linguagem do destino humano - não requer precisão particular em sua representação das operações do mercado financeiro, e é inteiramente produzida, em vez de impedida, pela condensação dramática. Quando Santa Joana é considerada, de modo perverso, como sendo primeiramente sobre poesia e não sobre capitalismo (ou sobre organização revolucionária), a peça nada perde de sua pegada marxista, pois a base que une Fausto e Bocarra é a identidade histórica (a "unidade de processo" de Schwarz) de uma classe; e uma vez que reconheçamos essa identidade, o enredo pode ser visto, em si, como construído sobre outra narrativa na forma de uma peripécia marxiana: "Sem heroísmo, como é a sociedade burguesa, esta não mais requer heroísmo, sacrifício, terror, guerra civil e a subjugação

39 SCHLEGEL, Friedrich. Athenäums-Fragment 67; in: Fragmente der Frühromantik 28. 
das nações para vir a existir". ${ }^{40}$ A burguesia emergiu em sangue e glória, mas teve rapidamente que reprimir suas grandes ideias, e qualquer um que nelas ainda pensasse teve que se submeter aos negócios, ao ganhar dinheiro.

O pastiche - novamente, bastante diferente do pastiche que é praticamente um procedimento padrão modernista, e também em tudo diferente da reanimação das formas mortas praticada pelo pós-modernismo - funciona de modo diferente em A ópera dos três vinténs, na qual o comportamento de classe típico é transmitido por meio das classes. $\mathrm{O}$ exemplo óbvio é a indústria burguesa transmitida pelos desfavorecidos: a indústria da mendicância de Peachum e, mais importante, o "O que é o roubo de um banco diante da fundação de um banco?"41 de Mac. Mas o exemplo sobre o qual Brecht parece ter despendido maior energia, ao menos se forem seguidas suas “dicas para atores", é o do amor, ou, mais apropriadamente, o da ideologia do amor, daquele desacreditado "maldito texto do "consegue sentir meu coração bater". ${ }^{42}$ Quando Mac, o notório criminoso, se casa com Polly, filha do agente de mendicância e sua segunda pretendente, em um estábulo, e em cujo casamento o buffet é servido pelos membros de sua gangue, os elementos estão dispostos para a paródia desbragada. E, de fato, recebemos algo disso - uma ponta sobre a distinção entre Chippendale e Luíz XIV, normalmente omitida nas produções contemporâneas da peça, é pura bufonaria ao estilo dos irmãos Marx $^{43}$. Porém a ironia não é tão direta quanto parece.

Os atores devem evitar representar esses bandidos como uma gangue daqueles indivíduos patéticos com lenços vermelhos ao redor de seus pescocos que animam feiras, e com os quais nenhuma pessoa respeitável tomaria um copo de cerveja. Eles são homens naturalmente dignos: um pouco corpulentos, mas em tudo (à parte suas profissões) sociáveis. ${ }^{44}$

O espetáculo de criminosos colocados na situação de um casamento burguês em um estábulo é absurdo não porque os criminosos são bufões, mas porque são, à parte suas profissões, burgueses (Bocarra, o empresário proeminente de A Santa Joana dos Matadouros, é igualmente - à parte

40 MARX, Karl. Der achtzehnte Brumaire des Louis Napoleon. MARX, Karl and Friedrich Engels, Werke, v. 8. Berlin: Dietz, 196o, p. 116.

41 BRECHT, Bertolt. Die Dreigroschenoper. Werke, v. 2, p. 239.

4,2 BRECHT, Bertolt. Die Dreigroschenoper. Werke, v. 2, p. 244.

43 BRECHT, Bertolt. Die Dreigroschenoper. Werke, v. 2, p. 433.

44. BRECHT, Bertolt. Die Dreigroschenoper. Werke, v. 2, p. 305. 
sua profissão - sociável). Mesmo a bufonaria genuína está adequada a esse modelo. A ponta risível normalmente omitida, que foi mencionada acima, ocorre às custas do "Capitão" Macheath, o desfavorecido pretensioso, que não sabe a diferença entre Chipendalle e Luiz XIV, mas finge sabê-lo. Aqui a bufonaria parece operar na direção esperada. Contudo, os comparsas de Macheath, que sabem qual é a diferença, permitemse serem corrigidos. Assim, a ignorância de Mac é um luxo, não uma privação: ele não é um ignorante, mas um inculto.

Desse modo, quando Mac, no momento em que está montando sua casa em um celeiro com um relógio Chipendalle roubado, entoa, momentos mais tarde, "Todo começo é difícil", ele não está citando o famoso verso de Goethe em Hermann und Dorothea, mas repetindo o clichê no qual esse verso se tornou. Brecht, por outro lado, está citando Goethe. O verso de Goethe continua: “Todo começo é difícil; mais difícil ainda é começar uma família" - essa última palavra traduzindo "Wirtschaft", mais comumente "empresa" ou "negócio". Essa cena toda, com seu cenário semi-rústico no meio de Londres, é um comentário sobre Hermann und Dorothea: com sua má reputação, na posição da refugiada Dorothea, ele está repetindo as palavras do pai respeitável (e, de fato, está fazendo uma combinação prática), enquanto é Polly, no centro do conflito entre a família como empresa e a família como união amorosa, quem ocupa a posição do pai, e quem, de fato, incorpora os impulsos contraditórios personificados no "Wirtschaft" de Goethe:

É absolutamente desejável que Polly Peachum impressione a plateia como uma jovem virtuosa e agradável. Se, na segunda cena, ela demonstrou seu amor inteiramente desinteressado, agora ela exibe essa percepção prática sem a qual a primeira cena teria resultado em mera frivolidade..$^{45}$

As múltiplas implicações dessa paródia poderiam ser buscadas nos recônditos mais profundos da cena, mas, nesse momento, o que é importante é que, enquanto o tema da cena é, claramente, a questão de classe - especialmente a substância econômica do sentimento burguês -, é somente sobre classe por ser, primeiramente, sobre poesia.

Por certo, há muito mais para o teatro do que para a poesia. "O teatro épico é gestual", escreveu Benjamin. "Em que medida ele pode

45 BRECHT, Bertolt. Die Dreigroschenoper. Werke, v. 2, p. 434. 
ser poético no sentido tradicional é uma questão à parte". ${ }^{46}$ Mas o que é o gesto brechtiano? Para Benjamin, trata-se de uma questão de interrupção, de enquadramento. Benjamin chega a uma conclusão apropriada por meio da seguinte passagem:

Em suma, a ação é interrompida. Podemos nos aprofundar aqui e considerar que a interrupção é um dos procedimentos fundamentais de toda articulação formal. Ela atinge muito mais do que a esfera da arte. Trata-se, para tomar apenas um aspecto, da base da citação. Citar um texto implica em romper com os laços de seu contexto. Faz sentido, portanto, que o teatro épico, que é baseado na interrupção, seja citável em um sentido específico. A capacidade de citação de seus textos não tem nada de extraordinário. No que concerne ao gestual que esse teatro utiliza, tem-se aqui uma questão de outra ordem.

"Tornar os gestos citáveis" é um dos feitos fundamentais do teatro épico. ${ }^{47}$

A questão da citação, longe de ser "uma questão de outra ordem" em relação à literariedade tradicional de Brecht, é, na verdade, a tradição da literariedade do dramaturgo. A citação - o girar e rodar da repetição do "penhasco a penhasco" de Hölderlin, a repetição irônica de "Todo começo é difícil”, de Goethe - é precisamente gestual. De fato, como se verificou, esse último gesto poético é indissociável de um conjunto de outros gestos: aqueles de Polly, Mac e dos subordinados de Mac. "De onde o teatro épico retira seus gestos?", pergunta Benjamin. "Os gestos se encontram na realidade". ${ }^{48}$ Certamente correto, mas não muito útil. De qual ordem de realidade o teatro épico retira seus gestos? Brecht "torna os gestos citáveis" precisamente ao citá-los, o que constitui outro modo de dizer que eles já são citáveis. A ordem de onde são retirados é uma ordem textual. O "maldito texto do "consegue sentir meu coração bater" 49 pode se referir ao Lieder romântico, do mesmo modo que "Todo começo é difícil” se refere a Goethe. Contudo, também pertence igualmente ao modo como os amantes agem um com o outro, como a repetição

46 BENJAMIN, Walter. Was ist das epische Theater?” [primeira versão]. In: Versuche über Brecht. Frankfurt am Main: Suhrkamp, 1966, p. 9 .

47 BENJAMIN, Walter. Was ist das epische Theater? [segunda versão]. In: Versuche über Brecht, p. 26-27.

48 BENJAMIN, Walter. Studien zur Theorie des epischen Theaters. In: Versuche über Brecht, p. 31 .

49 BRECHT, Bertolt. Die Dreigroschenoper. Werke, v. 2, p. 239. 
de chavões pertence ao modo como as pessoas agem em um casamento. Esses são dois tipos diferentes de texto - o gesto em si deve ser experienciado como espontâneo, enquanto o gesto literário é parte de um campo estético que se supera a si mesmo -, porém são ambos textos, ou não seriam citáveis. Como as notas para atores deixam claro, elementos estritamente gestuais são uma questão de ideologia corporificada, um roteiro social: "Esforços para não escorregar em uma superfície escorregadia se tornam um gesto social tão logo escorregar signifique perder o rosto" ${ }^{50} \mathrm{O}$ procedimento adotado pelo pastiche brechtiano e pela atuação gestual é o mesmo, qual seja, a citação ou o enquadramento de um texto pré-existente, de modo a criar uma unidade de sentido.

No que diz respeito à música, a questão do gesto adquire uma nova densidade. Em "Do caráter gestual da música”, que precede os primeiros comentários sobre o gesto publicados por Brecht, Kurt Weill declarou que, "hoje, o compositor não deve mais abordar seu texto a partir de uma posição de prazer sensual". ${ }^{11}$ Aqui, Weill está discutindo criticamente o problema brechtiano do entretenimento-mercadoria. Contudo, o que é ali proposto é, ao mesmo tempo, mais radical e menos pudico do que sua afirmação sugere. O alvo da crítica de Weill é o "teatro da época passada", que era "escrito para o prazer sensual. Sua intenção era excitar, irritar, despertar e aborrecer (kitzeln, erregen, aufpeitschen, umwerfen) o espectador". ${ }^{52}$ Logo, "irritar" e "aborrecer" estão incluídos sob a rubrica do "prazer sensual”. O que Weill proíbe ao que ele denomina "música gestual" é provocar qualquer tipo de estado emocional no espectador. Isso não é exatamente uma surpresa, visto que está bastante alinhado com os anátemas de Brecht lançados sobre efeitos teatrais como a "empatia coagida". ${ }^{53}$

Porém, como vimos, a geração de estados emocionais nos ouvintes é parte do que é a música. Weill parece ter se tornado vítima de si mesmo: o que a música é proibida de fazer é precisamente o que a distingue das outras artes. Há, de fato, a solução modernista paradigmática: uma exploração imanente da música como um medium, possível graças à base do campo restrito bourdieusiano. Mas essa linha de fuga é precisamente o que Weill procura superar:

50 BRECHT. Über gestische Musik. In: Schriften zum Theater, p. 253.

$5^{1}$ WEILL, Kurt. Über den gestischen Charakter der Musik. In: DREW, David (org.). Kurt Weill: Ausgewählte Schriften. Frankfurt: Suhrkamp, 1975, p. 41.

52 Über den gestischen Charakter der Musik, p. 40.

53 Ver BRECHT, Schriften zum Theater, p. 210-212. 
O desenvolvimento recente da música tem sido predominantemente estético: emancipação em relação ao século XIX, luta contra as influências extramusicais (música de programa, simbolismo, realismo), retorno à música absoluta. [...] Hoje estamos um passo à frente. Uma separação clara está ocorrendo entre aqueles músicos que [...], como em um clube privado, trabalham na solução de problemas estéticos, e aqueles músicos que vão se empenhar em embalar qualquer audiência..$^{54}$

Mesmo que o momento do desenvolvimento imanente da música seja visto como um passo à frente, dois imperativos contrários são sugeridos de imediato: embalar uma audiência para além do restrito campo especializado dos músicos e experts; e produzir sentidos para além daqueles que somente uma audiência restrita valoriza, o que significa criar sentidos que não são puramente música imanente. Esses dois imperativos parecem alinhados, e ambos têm em comum certo apelo popular. Porém, na verdade, como é do conhecimento de Weill, eles estão em profundo conflito. Em uma sociedade de mercado, o primeiro imperativo só pode ser concretizado colocando-se o mercado em risco ("qualquer audiência"). Quanto ao segundo imperativo, o de produzir sentidos políticos do tipo preconizado por Weill, tal asserção é indiferente para o mercado; esse imperativo não é, na verdade, comercializável, uma vez que sentidos que podem ser vendidos - sentidos para os quais existe demanda - não são sentidos em absoluto, mas mercadorias. Um sentido político que satisfaz uma demanda não é um sentido, mas um produto comprável de identificação social, como uma insígnia.

Qual a solução de Weill? Seu próprio comentário em "Do caráter gestural da música", ou em outros textos, não é particularmente útil a esse respeito. Contudo, o exercício de Weill é completamente claro. (No que se segue, continuaremos a lidar quase que exclusivamente com a música, o texto e os escritos teóricos de Brecht e Weill - os dois primeiros se fazem necessários, mas, de modo algum, são aspectos suficientes para a performance operística. Para uma descrição mais completa, vale a pena mencionar que a produção atual de Berliner Ensemble para $A$ ópera dos três vinténs, dirigida por Robert Wilson - a qual foi apresentada em São Paulo em novembro de 2012 -, compreende os procedimentos de desidentificação sublinhados aqui com tremenda força, principalmente no que

54. WEILL, Kurt. Verschiebungen in der musikalischen Produktion. In: HINTEN, Stephen e SCHEBERA, Jürgen (orgs.). Kurt Weill: Musik und Theater: Gesammelte Schriften, mit einer Auswahl von Gesprächen und Interviews. Berlin: Henschelverlag, 199o, p. 45 . 
diz respeito à direção musical, de modo próximo ao espírito das técnicas de Brecht e Weill que estamos discutindo.) A "Canção dos canhões", de $A$ ópera dos três vinténs, é uma variação em marcha de uma música de bar para se cantar junto, a qual pode ser genericamente classificada como uma balada de quartel. Como toda boa música para se cantar junto, ela pode muito bem embalar um ouvinte que esteja familiarizado com a canção, de modo que ele deseje cantar junto, e a razão pela qual tal tipo de música tem esse poder é algo que talvez um dia a ciência possa explicar. Entretanto, alguns ouvintes podem não se sentir tão motivados, e o fracasso da motivação é, em princípio, passível de explicação. Mas, para a produção de sentido, esse efeito ou sua falha são irrelevantes. A "balada de quartel" - a expressão é de Kipling - se torna um feito notável nas mãos de Weill, uma citação. A “Canção dos canhões” enquadra o gesto e, ao fazê-lo, cria um sentido, que é o de apresentar a camaradagem militar como extremamente repugnante.

O texto de Brecht é também uma citação, um pastiche de cantigas em marcha de Kipling, como "Screw Guns":

For you all love the screw-guns -

the screw-guns they all love you!

So when we call round with a few guns,

o' course you know what to do - hoo! hoo!

Jest send your Chief an' surrender -

it's worse if you fights or you runs:

You can go where you please,

you can skid up the trees,

but you don't get away from the guns. ${ }^{55}$

No texto de Brecht, racismo e genocídio passam do subtexto para o texto de uma forma deliberadamente nada sutil. No papel, acontece de forma mais branda, mas, no empolgante contexto de refeitório de Weill, é espetacular.

55 KIPLING, Rudyard. Barrack-Room Ballads and Other Verses. Leipzig: Heinemann and Balestier, 1892, p. 19. [N.T.] Tradução literal: "Por todos vocês amarem os canhões - / os canhões todos amam a vocês! / Então quando os visitarmos com algumas armas, / claro que vocês sabem o que fazer - hoo! hoo! / Apenas enviem seu líder e se rendam - / é pior se vocês lutarem ou correrem: / Vocês podem ir aonde quiserem, / vocês podem se embrenhar / mas vocês não podem se ver longe das armas". 
The troops live under

The cannons' thunder

From cape to Cooch Behar.

And if it rained one day,

And they had chanced to stray

Across a different race,

Brown or pale of face,

They made them, if they liked,

Into their beefsteak tartare. ${ }^{56}$

Qual é a fonte da horripilância da "Canção dos canhões”? Como tantas outras músicas em A ópera dos três vinténs, a marcação do tempo já é uma citação: "Foxtrote-Tempo". ${ }^{57}$ (As análises musicais que se seguem, embora não sejam exaustivas, presumem certa familiaridade com termos musicais básicos. Com isso, não se pretende desqualificar leitores que não tenham tal familiaridade. Ao contrário, é uma ferramenta para se argumentar sobre música e, nesse caso, sobre citação musical e alienação musical, por meio do texto. $\mathrm{O}$ argumento pode ser melhor provado ou refutado, igualmente para músicos e não-músicos, pela escuta atenta à performance da canção que, como na gravação original de Lewis Ruth -Band, está afinada com o espírito das coordernadas de Brecht e Weill. A análise musical somente fornece um índice para tal escuta atenta). O ritmo básico é um foxtrote (ritmo quaternário com ênfase no contratempo) e a parte introdutória do trompete desenvolve um motivo de jazz, culminando no clichê do compasso de 6 do ragtime. Mas o "suingue" do motivo inicial é escrito como uma colcheia pontuada, seguida de uma semicolcheia, e é para ser tocada como está escrita, portanto "sacode" em vez de "suingar". A linha atonal de saxofone lembra a chamada e a resposta do jazz - exceto quando se chega a um tempo adiantado que interrompe a linha de trompete, em vez de repeti-la e reforçá-la. Os compassos de introdução não conduzem à tonalidade do verso, ao contrário, não possuem nenhum centro tonal ou direção óbvia. A linha melódica angular da introdução - característica que se torna clara quando,

56 WEILL, Kurt e BRECHT, Bertolt, Die Dreigroschenoper [Score]. Vienna: Universal Edition, 2008, p. 251-252. O primeiro dístico é emprestado da tradução de Mannheim e Willet. [N.T.] Tradução literal: "As tropas vivem embaixo / Do trovoar dos canhões / Do Cabo a Cooch Behar. / E se chovesse algum dia, / E eles tivessem a sorte de vagar / Em meio a uma diferente raça, / De rosto pálido ou marrom / Eles os transformariam, se desejassem / No seu bife tártaro".

57 WEILL, Kurt and Bertolt Brecht, Die Dreigroschenoper [Score], p. 44-55. Die Dreigroschenband [Lewis Ruth-Band], Die Dreigroschenoper: The Original 1930 Recordings. Teldec/Warner, 1990. 
na primeira repetição da ideia inicial, o intervalo de quinta é comprimido em uma quarta aumentada no terceiro compasso - não é para ser subordinada à dança. Enquanto isso, a instrumentação - em especial, o uso dos metais graves - enfatiza a relação entre a música popular de dança e a marcha, uma conexão que coopera com o significado da canção. Quando a canção aporta em um centro tonal (compasso 7), o movimento harmônico subjacente se torna convencional, atado a um ciclo de quartas (ver, especialmente, os compassos 14 a 16), que pode ser intuído ou analisado. Mas essa estrutura é desfamiliarizada quando se evitam tríades e os movimentos que elas implicam, quase que completamente: a superfície harmônica consiste em conjuntos pareados de quintas justapostas nos tempos fortes e nos contratempos. O resultado também é desfamiliarizado - os movimentos são convencionais, mas agora roubados de qualquer ilusão de necessidade - e vagamente orientado, o que é enfatizado pela melodia, em grande parte, pentatônica. A canção torna-se diatônica e tonal somente com o refrão em marcha, que, na série de mínimas descendentes ("cape to Cooch Behar"), evidencia um acorde menor (F\# menor) e leva à sua dominante - o primeiro acorde convencionalmente destacado na canção. Essa é a música de bar - ou de uma estação de recrutamento. Mas a voz central, um abstêmio ou um pacifista, ainda coloca esse tom em dúvida. A dominante dura muito tempo, comprimindo-se em um acorde diminuído em vez de progredir. Por fim, à medida do barbarismo da letra, chega-se a uma cadência que se centra em outra dominante evidente, o que acontece no compasso 34, no clímax da canção (o "beefsteak" antes de "tartare"). Mas a cadência implícita é duas vezes falsa, enganosa tanto sobre para onde vai, quanto sobre de onde vem. Deveria levar a Lá menor, mas, em vez disso, leva a Ré menor. E, enquanto a melodia em "They made them, if they liked" (compasso 32) sugere que estamos, basicamente, em Fá\# menor, o compasso 33 já está em Ré menor. Portanto, a falsa cadência não é apenas falsa, mas, em vez de levar a algum lugar surpreendente, leva exatamente a lugar nenhum. O efeito geral, se olharmos de perto, é a remoção de todos os sentidos de naturalidade das estruturas convencionais subjacentes. A canção segue muito de perto as formas convencionais - foxtrote, marcha, balada de quartel; ciclo de quartas, melodia altamente nachsingbare ${ }^{58}$, cadência climática - para emprestar seus efeitos, enquanto as desnaturaliza por meios formais que não são efeitos, exceto à medida que tais efeitos visam o "efeito de desidentificação", expressão brechtiana diversamente

58 [N.T.] Em alemão, o termo nachsingbare está relacionado à ideia de uma música que pode ser facilmente cantada. 
traduzida, que, nos termos do presente artigo, não é estritamente um efeito, mas sim um conjunto de técnicas para evitar ou formatar efeitos e submetê-los a interpretações. Tudo isso é simples de entender como imanente na canção, o que torna difícil de imaginar que qualquer ouvinte negue que o produto dessas distorções formais não seja profundamente assustador.

"Hoje, o compositor não deve mais abordar seu texto a partir de uma posição de prazer sensual". ${ }^{59}$ Se, por um instante, imaginássemos colocar um hino de guerra em um filme patriótico sancionado pelo Estado, a primeira coisa que o compositor teria em mente seria produzir um efeito de canção para se cantar junto, um esprit de corps identificatório, na maior quantidade possível de pessoas. Se imaginássemos a construção de um filme comercial, a primeira coisa que o compositor teria em mente seria a mesma já referida, mas por uma razão diferente: apelar à maior quantidade possível de pessoas que desejem experienciar um esprit de corps identificatório. As versões de Brecht e Weill funcionam de modo inteiramente diferente, visto que não é necessário sentir a força da música para cantar junto (ainda que se precise entender seu sistema de citação, se não, sua especificidade) para entender o sentido de Weill, que é o de fundir a brutalidade da lírica de Brecht com a coesão social do esprit de corps militar, o que não é tão diferente do significado da dança de salão. Ao fazê-lo, impõe-se uma interpretação.

Porém, haverá chances de se sentir sua força: a "Canção dos canhões" permanece, à parte isso tudo, um estimulante. Isso é irrelevante para o sentido dessa música como uma obra de arte, mas está longe de sê-lo para o sucesso de "Canção dos canhões" como um entretenimento popular. Como diz Brecht, "o teatro permanence teatro, mesmo quando é teatro pedagócio; e, na medida que é bom teatro, é diversão". ${ }^{60}$ Se “Canção dos canhões" falhasse como estimulante, isso não implicaria mudança de seu sentido, mas também A ópera dos três vinténs não teria sido traduzida para dezoito línguas e encenada mais de $10 \mathrm{mil}$ vezes nos cinco anos anteriores à emergência do nazismo, e nem se falaria dela aqui hoje $\mathrm{e}^{61}$. "Até a cena do estábulo, a plateia parecia fria e apática, como se previamente convencida de que aquilo resultaria em um fiasco. Então, depois da 'Canção dos canhões', um brado inacreditável se fez ouvir, e

59 WEILL, Kurt. Über den gestischen Charakter der Musik. In: DREW, David (org.). Kurt Weill: Ausgewählte Schriften. Frankfurt: Suhrkamp, 1975, p. 4.1.

60 BRECHT. Vergnügungstheater oder Lehrtheater? In: Schriften zum Theater, p. 66.

61 Ver BRECHT, Werke, v. 2, p. 4,2. 
dali para frente estava maravilhosamente claro que o público estava conosco". ${ }^{62}$

“Que não haja ópera aqui!", ${ }^{63}$ exige Mac em uma obra chamada de ópera, uma palavra que se pretende tão irônica quanto os "três vinténs" que a sucede ${ }^{64}$. O gesto é ecoado (mas não citado) cerca de vinte anos mais tarde, no Rio de Janeiro, pelos compositores Janet de Almeida e Haroldo Barbosa:

\section{Pra que discutir com madame}

Madame diz que a raça não melhora

Que a vida piora por causa do samba

Madame diz que o samba tem pecado

Que o samba, coitado, devia acabar

Madame diz que o samba tem cachaça

Mistura de raça, mistura de cor

Madame diz que o samba democrata

É música barata sem nenhum valor

Vamos acabar com o samba

Madame não gosta que ninguém sambe

Vive dizendo que samba é vexame

Pra que discutir com Madame?

Vamos acabar com o samba

Madame não gosta que ninguém sambe

Vive dizendo que samba é vexame

Pra que discutir com Madame?

Vamos acabar com o samba

Madame não gosta que ninguém sambe

Vive dizendo que samba é vexame

Pra que discutir com Madame?

62 LENYA, Lotte. That Was a Time. Theater Arts, maio de 1956, p. 93.

63 BRECHT, Bertolt. Die Dreigroschenoper. Werke, v. 2, p. 434.

64. Ver, como exemplo, o ensaio Commitment to Opera, de Weill. In: WEILL, Kurt. Bekenntnis zur Oper. In: Ausgewählte Schriften, p. 29-31. 


\section{Duiú run diú...}

No carnaval que vem também concorro

Meu bloco de morro vai cantar ópera

E na avenida entre mil aperto

Vocês vão ver gente cantando concerto

Madame tem um parafuso a menos

Só fala veneno, meu Deus, que horror

O samba brasileiro, democrata

Brasileiro na batata é que tem valor. ${ }^{65}$

O elenco de personagens parece direto: Madame; o protagonista, que mora em um bairro da classe operária, pertence a uma escola de samba e presumivelmente trabalha para Madame; e a escola de samba, uma metonímia para "entre mil aperto" no Carnaval, em si uma metonímia para o povo brasileiro. Pesquisando-se de modo mais aprofundado, descobre-se que "Madame" era uma pessoa real, a conservadora crítica cultural Magdala da Gama de Oliveira, também conhecida como "Maggy", que tinha colunas importantes no rádio e no jornal Diário de Notícias e que, recentemente, foi identificada como "Madame" em um

65 ALMEIDA, Janet de e BARBOSA, Haroldo. Pra que discutir com madame? Continental, 1945. A ordem da letra, como foi apresentada, segue GILBERTO, João. João Gilberto Live in Montreux. Elektra/Musician, 1986. Devo muitos agradecimentos a Marcelo Pretto por desenterrar a gravação de 1945. Além das sensibilidades de performance e arranjo, marcadamente da década de 1940, o que é mais impressionante, na gravação original de Janet de Almeida, é que a citação de Tchaikovsky é um pouco mais abstrata, sugerindo que João, acompanhando Tchaikovsky de perto, deliberadamente enfatizou a citação. Também na gravação de 1945, a citação segue "gente cantando concerto", em vez de vir antes dessa frase. Liricamente, é uma diferença trivial, mas vale a pena pensar que o interlúdio é usado para modular. Na versão de Janet de Almeida, o interlúdio e a modulação são utilizados para introduzir uma breve coda no final da canção. Na performance de João Gilberto, o interlúdio e a modulação são utilizados na própria forma, de tal maneira que a canção, indo da primeira para a segunda parte, de um lado para o outro, modula da tonalidade de Ré maior para a de Mi Maior. (Aqui devo agradecer Marcelo Pretto novamente por pontuar a importância desse fato). Na versão de Janet de Almeida, em outras palavras, a piscadela para a burguesia é uma reflexão tardia, enquanto, na gravação de João Gilberto, é trazida para a própria estrutura da canção. Há razões puramente musicais para essa alteração feita por João Gilberto, mas ela também pode ser entendida como um comentário sobre a gravação de Janet de Almeida. 
ensaio do jornalista e compositor Fernando Lobo ${ }^{66}$. Sob uma perspectiva histórica, a posição do protagonista se torna mais complicada: ele ainda pertence à classe trabalhadora, porém o conflito narrativo entre ele e Madame é apenas metaforicamente uma luta de classe, visto que o conflito cultural que se dá em torno do protagonista ocorre inteiramente entre jornalistas: não apenas "Maggy" e Fernando Lobo, mas também Janet de Almeida e Haroldo Barbosa eram jornalistas, e no caso dos três últimos, também compositores.

Por mais sugestivo que seja, esse sentido histórico é essencialmente isolado. Trata-se de um aspecto não desprovido de interesse que um pouco de pesquisa nos permite observar. É sintomático de um campo ideológico reconhecível. Mas não se tentará aqui inscrever esse sentido histórico em um campo normativo, e até onde vai o sentido público da canção, estamos de volta onde iniciamos.

Ou poderíamos ficar apenas com o pequeno interlúdio sem palavras antes da penúltima estrofe, o qual é uma paráfrase muito próxima dos compassos 20 a 24 do Concerto para piano $n^{0} 1$ de Tchaikovsky ${ }^{67}$. Aqui, o sentido histórico da canção - a apropriação da subjetividade política da classe operária pela burguesia progressista - está inscrito diretamente na matéria musical. Não contente em ser mais democrático e sensível do que Madame (e, possivelmente, também um dançarino melhor), o protagonista coloca a si próprio como mais erudito, uma vantagem que não estava à disposição do homem do morro. Sem o interlúdio, "cantando concerto" é o discurso aproximado de alguém que não tem uma ideia muito precisa do que é um concerto. Depois do interlúdio, “cantando concerto" é uma referência para o que foi abordado: a voz lírica se identifica com a classe operária, mas apenas quando "Madame" está na terceira pessoa, ou seja, quando a voz lírica se dirige ao público, que é composto pelas classes inferiores e pela burguesia. A passagem emprestada de Tchaikovsky é, no entanto, dirigida apenas para Madame, para a burguesia como tal.

Muito mais pode ser dito sobre e peculiar combinação entre a identificação popular e a distância irônica do que é relevante para o

66 Ver a entrevista com Haroldo Barbosa para O Pasquim 249 (1974). In: JAGUAR e SÉRGIO AUGUSTO (orgs.). Antologia do Pasquim, Vol. III: 1973-1974. Rio de Janeiro: Desiderata, 2009. Ver também GARCIA, Tania da Costa. Madame Existe. Revista da Faculdade de Comunicação da FAAP. Disponível em: http://www.faap.br/revista_ faap/revista_facom/artigos_madameı.htm

67 TCHAIKOVSKY, Pyotr Ilyich. Piano Concerto Number I in Bb Minor, Op. 23. GOLDENWISER, Alexandr (org.). P.I. Tchaikovsky: Complete Collected Works. v. 28. Moscow: Muzgiz, 1955 . 
argumento em questão. A forma musical só tem sentido aqui como uma citação, a qual se desdobra em duas: o empréstimo de Tchaikovsky e o que, à luz de Tchaikovsky, aparece como um empréstimo da forma do samba. Todavia, em nenhum dos casos a forma musical significa qualquer coisa que não seja seu status enquanto citação: ao mundo da música erudita de um lado, e ao mundo (idealizado ou real) da forma musical comumente orgânica. Contudo, a citação funciona aqui de um modo oposto ao seu funcionamento em Brecht e Weill. Pois, em Brecht e Weill, a citação é uma técnica de não-identificação, de modo que liberta o trabalho dramático da obrigação de produzir uma relação de empatia com a ação de modo a substituí-la por um questionamento. Já em "Pra que discutir com Madame", trata-se de uma técnica para a produção de uma dupla identificação, sendo a primeira uma identificação pública e universal (do eu lírico com o público), e a segunda uma identificação privada e particular (do eu lírico com a elite cultural).

Somos tentados a destacar que a escolha do Concerto para piano $n^{o} 1$ de Tchaikovsky é particularmente apropriada, ou porque nela também uma dança folclórica, no caso, ucraniana, é contrastada a um tema romântico, ou porque sua longa melodia introdutória, de onde a citação de Janet de Almeida e Haroldo Barbosa é tomada, é uma linha de fácil digestão que pode ser absorvida pela cultura industrial sem dificuldade $^{68}$. Mas, na entrevista citada acima, na qual Haroldo Barbosa canta um pouco do interlúdio, não há o que sugira que ele considere a canção como nada além de um jeu d'esprit, um gesto não enquadrado ${ }^{69}$. $\mathrm{O}$ enquadramento, equivalente brechtiano, deve envolver um ator dizendo algo razoável para outro autor, enquanto disfarçadamente pisca para o público. Mas a piscadela sem moldura é mais uma ideia sobre a duplicidade do que a duplicidade em si.

Teria sido conveniente para esta discussão se João Gilberto, ao resgatar a canção do esquecimento, tivesse vencido essa duplicidade de um modo brechtiano. Entretanto, a bossa nova é uma forma resolutamente anti-teatral ("Retrato em preto e branco", que João performa

68 Quatro anos depois de "Pra que discutir com Madame," o líder americano de banda Freddy Martin obteve êxito ao arranjar o tema introdutório para uma orquestra dançante. O rótulo no lado B do registro, lançado em 78 rpm: "Piano Concerto in B Flat - Fox Trot” (Bluebird, 1941). Martin construiu seu sucesso ao popularizar outros temas clássicos; não há dúvida de que ele é um dos alvos das críticas mais ferrenhas de Adorno sobre tal popularização. Posteriormente, uma letra foi adicionada e lançou-se a canção "Tonight we love".

69 Citações musicais diretas em solos de jazz geralmente funcionam, sem o mesmo excedente significado social, da mesma forma, como gestos insinuantes que reduzem a autonomia do processo em questão. 
logo antes de "Pra que discutir com Madame", em um famoso concerto, começa com uma série de pequenos intervalos que imita - na letra de Chico Buarque, na composição de Tom Jobim e na interpretação de João - um homem resmungando a si mesmo) e não tem interesse em trabalhar com a teatralidade ${ }^{70}$. Ao contrário, na execução de João Gilberto, o conflito social incorporado na letra de Janet de Almeida e Haroldo Barbosa é transformado, como ocorre com a bossa nova em geral, em um problema que a forma musical tenta suplantar. Apesar da abordagem e do aspecto político serem diferentes, o problema inventado e confrontado pela geração da bossa nova pertence ao caso de Weill: "criar uma música capaz de satisfazer as necessidades musicais da maior quantidade possível de estratos sociais, sem desprezar a substância artística". ${ }^{71}$ Em outras palavras, o projeto da geração da bossa nova constitui-se em se utilizar completamente dos avanços reais possibilitados pela segmentação de classe ao mesmo tempo em que cria uma música que, a princípio, não depende da segmentação para sua recepção. $\mathrm{Ou}$, mais propriamente, produzir uma arte musical que não seja apenas elitista, uma música que seja samba e Tchaikovsky ao mesmo tempo.

Comparado ao trabalho dos compositores da bossa nova, "Pra que discutir com Madame" (não sendo, claro, uma bossa nova) é, apenas para o interpelado Tchaikovsky e a modulação que isso naturaliza, banal em termos de composição ${ }^{72}$. Parece provável que a canção foi revivida por João mais por sua relevância temática para o projeto da bossa nova do que devido a qualquer interesse particular em sua forma. Contudo, as inovações formais da bossa nova são, na versão de João, impostas à canção: a estrutura de acordes é extremamente texturizada com elaborações para altas extensões; o ritmo do violão é complexo, derivado do samba: o polegar operando, na pulsação, independentemente dos outros dedos que estruturam o ritmo em variações sincopadas que sugerem (embora seja uma ilusão) uma liberdade completa de improvisação da repetição; os vocais são cantados sem vibrato ou glissando, próximos à qualidade vocal de uma conversa (essencialmente fundamental para a anti-teatralidade), entonação extraordinariamente precisa, e, o mais importante, a sugestão constante de uma relação completamente sem restrições entre a pulsação e a linha de síncope. Quando esses elementos são executados por uma só pessoa, de modo que a relação entre os três elementos centrais - pulsação, ritmo e vocais - é, em cada ponto, intencional, o resultado é

70 Ver GILBERTO, João. Live in Montreaux. Elektra/Musician, 1987.

71 WEILL, Kurt. Die Oper - wohin?. In: Kurt Weill: Musik und Theater, p. 68.

72 BRECHT. Über gestische Musik. In: Schriften zum Theater, p. 253. 
uma performance de excepcional densidade musical. Um índice dessa densidade é que João, em concerto, frequentemente repete uma forma inteira três ou mais vezes - e ainda não há a sensação de repetição, a tal ponto que não conseguimos reconhecê-la quando vem. Mas a bossa nova continua a ser uma forma artística popular: não só são acessíveis as canções em si, mesmo quando são de interesse formal substancial, mas também os elementos individuais estão ao alcance de quem quiser aprendê-los.

Pode-se dizer muito mais sobre a ideologia estética da bossa nova, a qual é o expoente na música de um populismo desenvolvimentista cujo ideologema, repleto de implicações contraditórias, constitui o desenvolvimento de forças produtivas não intermediadas pelos interesses do todo da população do país. O ponto a se enfatizar aqui, no entanto, é que o eclipse da bossa nova não é um ponto final artístico, mas sim histórico, pois o populismo desenvolvimentista é deslocado de modo decisivo por meio do golpe militar de 1964, da ditadura e pela integração com o capital norte-americano. A bossa nova em si continua a se desenvolver após o fenecimento de sua relevância histórica, atingindo o seu ponto alto no começo dos anos 1970 com “Águas de março”, de Tom Jobim³ . Mas, na época em que "Águas de março" foi gravada (1972), um novo movimento, a tropicália, já tinha ido e vindo. De fato, a bossa nova já havia se tornado um assunto de pastiche para os músicos do movimento tropicalista: "Coração vagabundo" (1967), de Caetano Veloso, é um grande exemplo de bossa nova; contudo, trata-se de uma tese magistral sobre a técnica composicional de Tom Jobim, e não o desenvolvimento ou a transformação dessa técnica ${ }^{74}$.

Como se sabe, a nova música do período ditatorial, a tropicália, reorienta brutalmente o dialeto do mais ambicioso projeto musical brasileiro. Os elementos a serem musicalmente aproximados não são elevados ou baixos - entre os quais nem a identidade, real ou ideal, é imaginada -, mas sim elementos modernos e arcaicos, que não devem ser sintetizados, mas tornados existentes em suas contradições patentes. $\mathrm{Na}$ canção-manifesto “Tropicália” (Caetano Veloso), por exemplo, os refrãos são organizados em opostos pareados ${ }^{75}$. Mas são organizados ao longo de linhas de contradição temporal, não de contradição de classe: bossa nova versus a palhoça, Ipanema versus Iracema - mas nunca choupanas

73 JOBIM, Antonio Carlos. Jobim. MCA, 1973.

74. VELOSO, Caetano e COSTA, Gal. Domingo. Polygram, 1967.

75 VELOSO, Caetano. Caetano Veloso. Philips, 1968. 
versus apartamentos em arranha-céus ${ }^{76}$. Em outra canção-manifesto, "Panis et Circenses" (Gilberto Gil e Caetano Veloso), essas contradições se tornam uma questão formal ${ }^{77}$. A melodia é deliberadamente insípidauma genial performance ao vivo, datando do período, serve também como um esforço corajoso de Marisa Monte para demonstrar quão difícil é tornar "Panis et Circenses" uma boa canção convencional. A melodia curta, tocada do modo mais deselegante possível; uma banda militar; uma cadência anticlimática perfeita seguida de um silêncio embaraçoso; um acompanhamento em meio tom que crianças seriam capazes de tocar; tudo isso é soterrado sob o peso das técnicas de gravação contemporâneas, particularmente a de montagem de tape - um desacelerando tocado por meio de um polegar sobre o rolo da fita de gravação, uma conversa de jantar aleatória, o "Danúbio Azul" - sob a direção de Rogério Duprat, que treinou com Stockhausen e Pierre Boulez. Na afirmação de Roberto Schwarz sobre esse efeito tropicalista, que expõe o conteúdo de mau gosto "à luz branca do ultramoderno", trata-se de algo "como um segredo familiar trazido à rua". ${ }^{78}$

A tropicália, que abordamos rapidamente aqui, marca um momento crucial, a brutalidade e a rapidez de transição entre uma sociedade proto-socialista e uma sociedade de direita integrada ao capital norte-americano que ocorre praticamente do dia para a noite; a tropicália registra todas as contradições do que mais tarde seria chamado de

76 Para uma versão melhor detalhada desse argumento, incluindo leituras atentas a algumas das canções aqui citadas, ver: BROWN, Nicholas. Postmodernism as Semiperipheral Symptom. In: Utopian Generations: The Political Horizon of Twentieth Century Literature. Princeton: Princeton University Press, 2005, p. 166-192. Quem já leu tal capítulo deve notar uma revisão desse argumento no presente estudo. $\mathrm{Na}$ discussão anterior, o elemento ideológico da tropicália era visto como sua hipotização de contradições, enquanto o elemento utópico estava nos desejos que as canções da tropicália buscavam, não-enfaticamente, atender. Eu não estava satisfeito com a segunda parte do argumento na época; nos termos do presente argumento, não poderia estar certo, uma vez que o último desejo é ajustado no mercado simplesmente como uma demanda. Nenhum desses argumentos anteriores é, contudo, precisamente errado. Ao contrário, a linha que divide os aspectos ideológicos e os utópicos - terminologia que não orienta a presente discussão - da tropicália passa não entre a canção e o desejo que ela satisfaz, mas sim através de ambos. Desejo, é claro, muito superior ao do mercado, que só pode canalizar alguns desejos em demanda. Enquanto isso, a hipotização das contradições é realmente ideológica. Mas, como veremos, mesmo a ideologia de Caetano Veloso tem, quando produzida através de uma forma musical, um aspecto em oposição, que é o fardo do argumento que se segue.

77 VÁRIOS. Tropicália ou Panis et Circencis. Philips, 1968.

78 SCHWARZ, Roberto. Cultura e política, 1964-1969. In: O pai de família e outros estudos. $2^{\text {a }}$ ed. Rio de Janeiro: Paz e Terra, 1992, p. 74 . 
pós-modernismo, de um modo que ainda marca tais contradições como monstruosas. Entretanto, a marca deixada pela tropicália na música brasileira foi provavelmente menor na música em si e maior no treinamento - em termos da ambição estético-política, assim como no âmbito musical - proporcionado a uma geração de músicos brasileiros. De fato, já no "álbum branco" (1969) de Caetano Veloso, um projeto inteiramente novo, desenvolvido a partir, porém distinto, daquele da tropicália, emergiu em todos os seus contornos ${ }^{79}$. A primeira coisa que se nota em Caetano Veloso é a diversidade de roupagens do álbum: uma tradicional canção de marinheiro baiana, um tango cínico dos anos 1930, uma balada extremamente elaborada dos anos 1940 e uma bossa nova lançada recentemente. Há, também, puros pastiches: uma marcha ao estilo de trio elétrico, um fado português, e uma tentativa de pop psicodélico britânico e rock de álbum ${ }^{80}$. Apenas nas duas últimas faixas do disco - uma de Caetano Veloso e outra de Gilberto Gil, seu primeiro colaborador e violonista - há uma aproximação reconhecível aos procedimentos tropicalistas: "Acrilírico" - uma palavra valise que combina "acrílico" (novo e sintético) e "lírico" (antigo e orgânico) para produzir o "acre" entre ambas - é um poema concreto falado que inclui fragmentos de som de tape; e "Alfômega", de Gil, talvez a destilação da alegre antisocialidade da tropicália, que constrói jogos de palavra concretistas em torno da palavra "analfabeto" e os coloca dentro do que é essencialmente uma canção de rock, tocada aqui de um modo que só pode ser descrito como moderno e deixando em aberto a questão se o rock é usado como uma espécie de cultura avançada ou cultura perifericamente derivada. Por certo que, à luz do que se observa no conjunto das faixas anteriores do álbum, essas duas músicas não devem ser entendidas de modo diferente das outras dez: a tropicália está incluída na miscelânea, e não é o princípio em si da miscelânea. Dentro do posicionamento do álbum de 1969, a lógica da tropicália já tinha sido superada.

Com exceção de momentos em que fazê-lo deformaria o material musical para além do reconhecível, o material do álbum é tratado de modo uniforme do começo ao fim, logo "Chuvas de verão" (um sambacanção de Fernando Lobo, da mesma época de "Pra que discutir com Madame") pode servir de ilustração para o procedimento seguido no álbum como um todo. São prescindidos os ornamentos orquestrais e

79 VELOSO, Caetano. Caetano Veloso. Philips, 1969.

8o Na ordem: "Marinheiro só", canção de tradição oral; "Chuvas de verão," de Fernando Lobo; "Cambalache," de Enrique Santos Discépolo; "Carolina” de Chico Buarque; "Atrás do trio elétrico," "Os Argonautas," "Lost in the Paradise" e "The Empty Boat", de Caetano Veloso. 
interlúdios presentes na gravação de Francisco Alves de 1948. (A linha de flauta é aludida em uma breve introdução assobiada que, diferentemente da gravação original, não se desvia da estrutura da canção). O todo da estrutura rítmica e harmônica - sendo o ritmo largamente diversificado e afrouxado, ainda que fortemente alinhado com o vibrar e o silenciar como no original, um samba-canção - é trazido pelo violão de Gil, cujo virtuosismo é totalmente discreto. Os vocais são cantados sem vibrato ou glissando, sonorizados de modo muito preciso e gravados próximos ao microfone, resultando em uma vocalização intimista: mesmo quando os vocais sobem (por exemplo, na primeira linha vocal e particularmente em “trazer uma aflição"), a variação dinâmica é mantida em redução, de modo que o efeito dramático do longo intervalo enfatizado na gravação original é minimizado e, assim, internalizado. (Mesmo em "Atrás do trio elétrico", os vocais são dobrados em vez de cantados com alta intensidade). Em outras palavras, ainda que a canção não seja bossa nova, os procedimentos nela seguidos estão de acordo com a sensibilidade da bossa nova. A versão em estúdio é particularmente notável. Rogério Duprat acrescenta uma parte orquestral que é, em si, um excelente acompanhamento, muito melhor do que a original para a qual muitas vezes alude. Contudo, as qualidades áureas da linha orquestral são completamente diferentes das partes de violão e vocais: é como se essas partes tivessem sido gravadas em um quarto, enquanto a parte orquestral tivesse sido gravada em uma catedral. O efeito geral é o oposto da maioria das produções em estúdio. Em vez de produzir a ilusão de uma performance sem interrupção, na qual "o processo de fusão atinge o espectador, que é imediatamente fundido e agora representa uma (sôfrega) parte passiva da totalidade da obra de arte", o resultado é "uma separação radical dos elementos". ${ }^{81}$ Isso ocorre inteiramente por razões brechtianas. A linha orquestral está excessivamente alta na mixagem. Uma vez que o acompanhamento orquestral é intermitente, isso serve para separá-lo mais à frente do violão e das bases vocais de modo a não dificultá-lo, ao mesmo tempo em que também dramatiza o "grande conflito primevo" entre estrutura e ornamento, que não pode ser simplesmente suprimido, pois constitui parte da forma popular. Em vez de serem combinados para produzir um efeito, os elementos são separados para narrativizar uma relação.

Confirmando tudo isso, estão as partes orquestrais misturadas em um único canal, de modo que, se um fone de ouvido é removido ou a equalização é movida inteiramente para um único lado, ambas podem

81 BRECHT. Das moderne Theater ist das epische Theater, p. 21. 
ser totalmente eliminadas. (As partes de violão e dos vocais estão misturadas nos dois canais, logo, não podem ser eliminadas). O conflito entre estrutura e ornamento é, assim, decidido em favor da estrutura. Isso é muito fácil, respondendo à questão que se supunha instaurar e obscurecendo totalmente o papel do ornamento na estrutura em si. O que é importante frisar no momento, contudo, é que esse procedimento é bem diferente do procedimento tropicalista. Onde, anteriormente, Duprat e seus colaboradores tinham usado a gravação em estúdio para ironizar brutalmente as matérias-primas culturais nela empregadas, o estúdio aborda o material musical - que agora aparece como estrutura em vez de matéria-prima - sem assumir uma posição superior a esse material. Não há, em outras palavras, ironia na nova relação com o material.

A única exceção possível constitui um caso interessante. A gravação de "Carolina”, de Chico Buarque, foi recebida escandalosamente como um ataque irônico. Sem o contexto, fica difícil entender o porquê. A gravação de Chico é dominada por um acompanhamento orquestral que é, respectivamente, meloso (cordas) e grudento (metais surdos), e com uma linha de percussão embaraçosamente - e quase inacreditavelmente, para uma gravação brasileira - fraca tocada com o chimbau. De fato, a gravação toda não é uma má aproximação de uma má aproximação norte-americana da bossa nova. Chico não faz muito com a linha vocal exceto, ocasionalmente, cantar fora de tom. Nem mesmo Chico se importou com "Carolina", que aparece como uma peça musical bem mais interessante na versão de Caetano ${ }^{82}$. A canção é desnudada precisamente da mesma forma que "Chuvas de verão" (a linha orquestral nem sequer entra até os últimos quinze segundos ou mais da canção), com Gil produzindo no violão uma maravilhosa destilação e revisão das estruturas rítmica e harmônica ao adicionar alguma cor e complexidade à vibração basicamente uniforme - um discreto shuffle de rock é brevemente introduzido - e à estrutura diatônica do material original.

Todavia, é complicado ver "Carolina”, de Caetano, como algo que não seja uma paródia. Chico é, naquele momento, um herói da esquerda culturalmente hegemônica, que é simpática ao marxismo mesmo onde este não está totalmente incorporado conceitualmente. Caetano, ainda que venha dessa esquerda - um de seus primeiros feitos musicais foi uma música incidental para uma produção de uma peça didática de Brecht ( $A$ exceção e a regra) - é uma figura para o que parece, em retrospecto, com um liberalismo insurgente. Chico é, entrementes, um amador de

82 WERNECK, Humberto. Gol de letras. In: HOLLANDA, Chico Buarque de. Chico Buarque: letra e música ı. São Paulo: Companhia da Letras, 1989, p. 76. 
talento, mas ainda um amador. "Profissionalismo" é um termo privilegiado no vocabulário de Caetano, como o fora para os primeiros modernismos antropofágicos do Brasil. O termo requer o mercado, não há dúvida, porém se refere, de modo mais imediato, ao anti-imperialismo da substituição da importação cultural, o desenvolvimento de uma indústria cultural local suficientemente especializado para ser capaz de competir com a cultura primeiro-mundista progressista. Essa é a ideologia estética dos modernismos periféricos de James Joyce a Oswald de Andrade a Chinua Achebe, a qual relega o amadorismo ao "diletantismo" (de acordo com Júlio Medaglia, compositor de vanguarda e arranjador da tropicália) e, supostamente, a autêntica cultura à "macumba para turistas" (de acordo com Oswald de Andrade, em uma frase que os tropicalistas gostavam de citar). Quando Caetano canta "Carolina" com uma entonação descontraída - vista em nenhum outro lugar do álbum e, virtualmente, em nenhum outro lugar de sua obra - é difícil não tomar o gesto como algo deliberado. Além disso, a letra - uma reminiscência de uma sedução que não deu certo - se presta facilmente a uma interpretação política: a fria Carolina representando a burguesia que dá as costas para “Uma rosa nasceu / Todo mundo sambou / Uma estrela caiu”, a voz lírica representando a vanguarda revolucionária tentando mostrar todos esses aspectos. Se a canção deve ser tomada como puramente romântica ou como uma alegoria política, a voz lírica se pinta em tons excessivamente lisonjeiros. A interpretação de Caetano, cantada num tom pouco acima de um sussurro, oferece apenas uma distância interna suficiente, em relação à voz lírica, para tornar-se um narrador machadiano: o revolucionário galante se revela um sedutor preguiçoso que Carolina deve ser sábia o suficiente para ignorar.

Em uma fala recente, Caetano afirma que a inspiração para a gravação foi uma jovem, a "anti-musa do Brasil" (note-se que "antimusical" foi uma palavra-chave na canção-manifesto da bossa nova, "Desafinado", de Antonio Carlos Jobim e Newton Mendonça) cantando “Carolina" em um concurso de talentos na $\mathrm{TV}^{83}$. Dificilmente se pode acreditar nisso. Por outro lado, essa fala confirma, em sua falta de credibilidade, tudo que foi dito acima. Tanto quanto os sentimentos inflados da canção popular dos anos 1940, de tradicionais canções de marinheiro, de marchinhas de Carnaval, de fado português, dentre outros, uma robusta cultura musical semiprofissional é uma parte da (e uma pré-condição) extremamente profissionalizada cultura musical no Brasil. Em outras palavras, esse relato é uma tentativa de tornar "Carolina" consistente

83 WERNECK, Humberto. Gol de letras, p. 8 . 
com o resto do álbum, e se isso não é plausível, então se tem um fracasso de "Carolina", não um contrassenso nas perspectivas do álbum. Uma consideração posterior é mais plausúvel, e mais interessante ainda:

Quando gravei, em 69, a 'Carolina' num tom estranhável [o adjetivo brechtiano é intencional?], (...) não era preciso agredir Chico para afirmá-la [para afirmar a nossa visão]. Porque estávamos seguros de que a criação de Chico, ela mesma, ganharia com a relativização. ${ }^{84}$

"Relativizar" sem "atacar", na verdade, tornar arte para relativizar, para alienar: em outras palavras, enquadrar. Esse é o modo do álbum em si. E, de fato, é esse relato que finalmente está adequado aos fatos musicais. As ambivalências de "Carolina" são destacadas mesmo que a destilação musical em si não seja uma forma de julgamento, e mesmo que tal destilação seja uma reverência.

No que tange ao procedimento apontado aqui, e sobre a lógica de separação de elementos que ele requer, todo o conteúdo lírico do álbum é radicalmente relativizado da mesma forma que se observa em "Carolina": "Os argonautas" pode nos mover para uma resignação navegante (“Navegar é preciso / Viver não é preciso"); "Atrás do trio elétrico" pode nos fazer querer dançar atrás de um grupo de Carnaval (“Atrás do trio elétrico / Só não vai quem já morreu”); “Alfômega” pode nos preencher com uma euforia de rock inteiramente inapropriada para o seu conteúdo. Por serem boas canções, elas certamente incitarão tais movimentos e sentimentos; e o choque efetivo que provocam é sua raison d'être mercadológica. Porém, promovendo ou não tais incitações, essas canções são, inegavelmente, a respeito desses estados emocionais, que se constituem em uma raison d'être de ordem completamente diferente.

A maneira de usar citações para produzir significado musical está muito bem alinhada com aquela buscada por Weill e Brecht; o sentido produzido é, obviamente, diferente. O projeto pós-tropicália será, então, como Caetano e Gil escrevem em uma canção do álbum Tropicália 2 (1993) sobre o Cinema Novo brasileiro, "outras conversas sobre os jeitos do Brasil". O que emerge do álbum como um todo é uma representação musical do Brasil elaborado a partir de um certo ponto de vista de classe, necessariamente incompleto e que exclui, sob todos os

84 VELOSO, Caetano. Verdade tropical. São Paulo: Companhia das Letras, 1997, p. 233-234. 
aspectos, influências estrangeiras ${ }^{85}$. De fato, esse é o princípio que guiará a carreira de Caetano dali por diante. Tropicália 2 detém, sob o ponto de vista do presente argumento, um nome equivocado: o álbum é, praticamente faixa por faixa (ainda que nenhum das canções seja repetida), uma sequência não ao Tropicália original, mas sim ao "álbum branco" de Caetano de $1969^{86}$. Esse princípio se tornou, em boa parte, o princípio da ousada música brasileira em si, reunindo músicos de extremamente diferentes gostos, abordagens e níveis de seriedade.

Os limites ideológicos desse projeto são evidentes. A princípio, não há razão para que esses modos e atitudes não possam, como em Brecht e Weill, ser atitudes de classe, atitudes profissionais, atitudes históricas, dentre outras. Mas, nesse caso, a estrutura nacional seria relativizada e, na prática, as categorias relevantes tendem a ser regionais. Elas são históricas apenas no sentido estrito de receberem os créditos por terem contribuído para o caráter nacional brasileiro. $O$ projeto se assenta inteira e confortavelmente sobre o liberalismo de Caetano (e com o neoliberalismo cultural contemporâneo dos Estados Unidos, que vem se tornando, cada vez mais, globalmente hegemônico). A visão de mundo de Caetano é de profunda simpatia para com as classes mais baixas que, apesar de tudo, são responsáveis pela maior parte da música brasileira. Todavia, sendo um filho da burguesia muito mais do que ele imaginava em 1964, sua simpatia não se estende a uma crítica da sociedade de mercado, que presume e requer, primeiramente, a existência de classes mais baixas. A questão aqui não é descrever a perspectiva política que Caetano deveria ter adotado, mas sugerir que a política requerida por sua prática musical aponta para uma direção bem diferente.

Mas a simpatia não se estende a uma inclinação para compartilhar o poder político ou econômico com os estratos da sociedade mais amplos, e, de fato, a atitude de Caetano, em direção a uma real democratização do poder político e econômico pode, na balança, ser dificilmente vista como progressiva ${ }^{87}$.

85 Eu só recentemente entendi que as canções políticas de Caetano não são inexplicavelmente ruins; eles são tentativas de incluir, nesse cânone, a tradição brasileira do protesto, que possui diferentes requerimentos formais, quando comparada à canção popular.

86 VELOSO, Caetano e GIL, Gilberto. Tropicália 2. Elektra, 1994.

87 Tomo o trabalho de Roberto Schwarz, Verdade tropical: um percurso de nosso tempo (In: Martinha versus Lucrécia: ensaios e entrevistas. São Paulo: Companhia das Letras, 2012, pp. 52-110), como sendo a análise definitiva sobre a posição política de Caetano Veloso. O artigo tem gerado discussões. Alguns dos comentários foram de má-fé; alguns simplesmente concordam com a posição de Caetano e discordam da visão de Roberto; alguns sentem a necessidade, ao defenderem a produção de 
Essa atitude não é, de qualquer forma, um caso isolado no Brasil. Uma atitude profundamente igualitária combinada com uma grande tolerância por materiais desiguais emerge, em Schiller, virtualmente no mesmo momento da própria Estética:

No estado estético tudo, até mesmo a ferramenta que se usa, é um cidadão livre, o qual tem direitos iguais aos mais nobres. [...] Aqui, no campo do surgimento da Estética, o ideal de igualdade - que o político fanático se alegraria em ver realizado - será cumprido ${ }^{88}$.

$\mathrm{O}$ que, mais do que qualquer outra coisa, reorganiza o materialrelações hierárquicas em meras diferenças, classes em nichos - é o mercado. Roberto Schwarz é quem resume a posição tropicalista:

essa acomodação do presente a si mesmo, em todos os seus níveis, sem exclusivas, era a imitação ou assimilação subjetiva - mais satírica do que complacente? - do ponto de vista da programação comercial da cultura. Também as estações de rádio ou de TV trabalham com todas as faixas de interesse do público, do regressivo ao avançado, desde que sejam rentáveis. O mundo cheio de diferenças e sem antagonismos toma a feição de um grande mercado. ${ }^{89}$

Schwarz está se referindo aqui à tropicália. Se estou correto em afirmar que o momento pós-tropicália subtrai a ironia do procedimento tropicalista, então a opção satírica desaparece e se fica apenas com a assimilação complacente ao mercado. E, de fato, Caetano Veloso adota essa linha interpretativa. Em uma apresentação, antes de cantar uma canção em espanhol, Caetano se lança em uma digressão sobre como cantar em línguas estrangeiras confere uma espécie de acesso privilegiado ao Outro. Uma batida, e então "Também é bom para se exibir ao mercado". Caetano faz as duas afirmações, a da digressão e a da citação, de modo sincero, mas a piada só funciona por causa da assimetria que existe entre ambas: a segunda coloca a primeira em dúvida, porém o contrário não é verdadeiro.

Caetano, de também defender sua política. Para os presentes objetivos, é suficiente notar o vão entre a posição política de Caetano Veloso e as políticas implicadas em seu projeto musical.

88 SCHILLER, Friedrich. Über die ästhetische Erziehung des Menschen, in einer Reihe von Briefen (1795), vigésima-sétima carta.

89 SCHWARZ, Roberto, Verdade tropical: um percurso de nosso tempo, p. 99. 
Uma posição cínica é preferível, contudo, a uma posição ingênua, e Caetano logo percebeu que não levar em conta as considerações do mercado - "muitas vezes, as únicas considerações decisivas" - não era mais uma opção ${ }^{90}$. "O que nos é importante", escreveu Weill em uma carta para o Musikblatter des Anbruchs (1929), "é que aqui, pela primeira vez, o avanço para uma indústria de consumo foi atingido". ${ }^{91} \mathrm{Com}$ a intenção de atingir "a maior quantidade possível de estratos sociais", Weill e Caetano tangenciam a borda da Gebrauchsmusik, uma música que satisfaz certas necessidades, nesse acaso, emocionais. Weill se expõe ao mercado por sua própria escolha. Para Caetano, como se verá, não se trata de uma escolha a ser feita. Depois da derrocada dramática das possibilidades reais de uma sociedade não-mercadológica, ele compreende a si mesmo como lutando em uma situação na qual "qualquer forma de utilidade é suficiente para tornar qualquer coisa e qualquer um 'um membro oficial do mundo das mercadorias"'. Em uma entrevista publicada em 1974, o cantor delineia com admirável concisão a subjugação de campos mais específicos pela indústria cultural:

Livre do patrocinador, do censor, do compromisso com a mediocridade das massas, o "pesquisador puro" é que irá dar saltos ousados; não sem risco, entretanto, de cair no vazio. Ou seja: de um lado, a Música, violentada por um processo novo de comunicação, faz-se nova e forte, mas escrava; de outro, a Música, resguardada ${ }^{92}$.

Cinismo e clareza de entendimento, ambos presentes aqui, se tornam difíceis de discernir.

Chegamos ao menos a um sentido aproximado do conteúdo ideológico das "outras conversas sobre os jeitos do Brasil” de Caetano Veloso: uma imagem liberal de um país repleto de diferenças sem conflitos, uma imagem que se parece, estranhamente, com o mercado. A prática do pastiche está diretamente insinuada pela real absorção da cultura pelo mercado, um processo que Caetano, ao mesmo tempo, celebra e observa com extrema clareza. Os antigos sentidos - modernistas, da bossa nova se tornam subitamente irrelevantes não porque cessaram de significar ou de se desenvolver, mas porque a rede que achou relevantes suas significações e desenvolvimentos foi subjugada pelo mercado. Quando a bossa

9o VELOSO, Caetano. Verdade tropical, p. 177-178.

91 WEILL, Ausgewählte Schriften, p. 54 .

92 CAMPOS, Augusto de. Conversa com Caetano Veloso. In: Balanço da bossa e outras bossas. $4^{\mathrm{a}}$ ed. São Paulo: Perspectiva, 1986, p. 200. 
nova recua para uma rede informal que parece não ter mais relevância quando confrontada com a exposição da indústria cultural brasileira, há a emergência de um novo grupo de possibilidades, as quais estão comprometidas com a relativização e apropriação de estilos obsoletos. Essa relativização, que, mais tarde, vem a ser identificada como pósmodernismo, deve ser absoluta: deve envolver uma ironia pós-moderna na qual, em razão da ausência da meta-narrativa mantida constante por redes não-mercadológicas, o único princípio de seleção disponível é o capricho do artista, o qual é então, necessariamente, colocado em uma posição superior aos estilos que agrupa. De fato, esse é o caso da Tropicália, com a vantagem supra-paradigmática da cultura pós-moderna que consiste no fato dessa mudança ser notada como intolerável: escravidão ou impotência. Caetano, no entanto, sobrepõe essa lógica:

(...) A inevitável eclosão da bossa nova é, comercialmente, natimorta e, culturalmente, vive safando-se do comércio, tanto quanto precisa dele, o que lhe possibilita apenas andar bem devagar. Estamos tentando achar a linha perdida. ${ }^{93}$

É surpreendente que Caetano conduza essa autópsia em nome da continuidade em vez do rompimento radical. O novo grupo de possibilidades é visto em termos de uma "trajetória perdida", que não é outra senão a narrativa fundadora da "linha evolutiva" que Caetano tem buscado, ao mesmo tempo, inventar retrospectivamente e introduzir no discurso musical brasileiro como um conceito inevitável, mas que não pode, se vai funcionar como um princípio, ser subordinada ao próprio gosto do cantor.

Vejo que é a muito duras penas que se conseguem alguns momentos de organicidade em nosso trabalho; que raramente alguma coisa reconhecível se adensa para logo depois se perder na confusão: a gente faz um samba quase sem querer de tão bonitinho, exulta por acreditar ter realizado um bom momento na trajetória dessa linguagem - eis que são tão poucos os músicos ainda capazes de ouvi-lo, enriquecê-lo, compreender o que ele pode significar,

93 VELOSO, Caetano. Primeira feira de balanço. In: VELOSO, C. O mundo não é chato. Org. Eucanaã Ferraz. São Paulo: Companhia das Letras, 2005, p. 153. Artigo originalmente publicado na revista Angulos, dos alunos da Faculdade de Direito da Universidade Federal da Bahia, em 1965. 
aprender com ele ou, no correr da História, reensiná-lo; e mesmo esses têm poucas oportunidades de responderem uns aos outros. ${ }^{94}$

Perguntamo-nos se, em vez de central para a tropicália, Caetano era de fato um tropicalista: o projeto pós-tropicalista já está expresso aqui, em sua plenitude, completo com seus tons liberais-nacionalistas, em 1965. Todavia, o que é importante notar nesse ponto é que o mercado se preocupa, da mesma forma, com a "linha evolutiva" ou uma "trajetória perdida" e com a segunda onda da bossa nova de protesto. Caetano escreve, como sempre, com admirável precisão. O que está em jogo não é o que a música significa, mas o que "pode significar" em termos de um desenvolvimento musical nacional quando este é abordado por alguém entendido no assunto. São duas as entidades que possivelmente se importariam, de modo plausível, com tal linha evolutiva. Primeiramente, a nação, o referente de "nós" e "nossa" - mas puramente em um sentido de comunidade imaginária - não um mercado nacional, pois o mercado nacional não é outro que não a "confusão" na qual a linha evolutiva vai “se perder”. Em segundo lugar, os músicos, os quais são capazes de discernir, em suas práticas, o material a ser desenvolvido por suas mãos, em outras palavras, um bourdieusiano campo restrito de músicos a "responder uns aos outros" - contudo, é precisamente a falta desse campo que Caetano lamenta. Não existem nenhuma das entidades às quais uma "linha evolutiva" pudesse, plausivelmente, importar. O mercado, no entanto, existe. Como se viu anteriormente, a música "precisa" dele; não há mais nenhum outro modo de distribuição que se iguale ao da indústria cultural. Mas Caetano, apesar de tudo, não está fazendo música para a indústria cultural, que é, novamente, a "confusão" na qual se perdeu tudo que merecia ser salvo.

Em outras palavras, a prática musical de Caetano requer uma política separada em relação ao apelo do cantor ao mercado, apelo esse que guina desconfortavelmente entre o realismo e o cinismo e apesar da ideologia liberal-nacionalista do cantor, a qual guina desconfortavelmente entre condescendência e paternalismo. Caetano descobriu, no mercado, uma condição de possibilidade para uma forma de sentido que é, em princípio e necessariamente, autônoma em relação ao mercado. Um modo de se refletir sobre isso é dizer, um pouco pateticamente, que já em 1965 a obra de Caetano apontava para a produção de sentidos para uma audiência que estava "por vir"; e ao menos nessa perspectiva sua obra representa uma certa resistência, ainda que frágil, ao presente. Um

94 VELOSO, Caetano. Primeira feira de balanço, p. $15^{2}$. 
outro modo de construírmos a reflexão seria dizer que, em um contexto neoliberal, quando o Mercado, enquanto horizonte de todos os esforços humanos, é o vetor mais forte (e praticamente o único vetor) no plano ideológico do capital, e a valorização universal é praticamente seu único (mas também o mais devastador em termos sociais) imperativo, Caetano apresenta um modelo valioso.

Nas atuais circunstâncias, a produção de sentido artístico - ou seja, a produção do que não pode ser valorado dentro de uma sociedade que subordina toda atividade à produção de valor - é, em si, uma forma de política. Não se trata meramente de uma questão de produzir uma linha de fuga ao longo da qual os artistas podem, dentro de campo cultural saturado de valor, produzir não-valor, ou seja, sentidos - ainda que os artistas possam experienciar essa linha de fuga dessa forma. Em vez disso, em um regime neoliberal - cuja essência é a exigência de que tudo seja valorado - a produção do não-valorizável aloja um "corpo estrangeiro" no ponto fraco da ideologia do capitalismo. A eficácia política de tal ato está, necessariamente, além do escopo deste ensaio. Nós estamos inicialmente preocupados com o problema de assegurar o sentido em meio ao horizonte ideológico de uma sociedade inteiramente saturada pelo mercado, ou seja, em assegurar a precondição da narrativa e da representação para que essas possam ter uma representatividade política. Os sentidos circulam ou fracassam em circular, se compelem ou fracassam em se compelir. O sucesso na primeira possibilidade, que é facilmente questionável, não garante sucesso na segunda possibilidade, a qual não é facilmente questionável. Entretanto, se poderia evitar repetir o erro dogmático de Schönberg, qual seja, o de porque $A$ ópera dos três vinténs era popular, ela não fora entendida.

Tradução

Aparecido Donizete Rossi e Renato Gonçalves Ferreira Filho

\section{Sobre o autor}

\section{Nicholas Brown}

Professor dos departamentos de Inglês e de Estudos Afro-Americanos da Universidade de Illinois em Chicago (EUA). Bolsista da Fundação Alexander von Humboldt e pesquisador visitante da Universidade Humboldt de Berlim (Alemanha). E-mail: cola@uic.edu 
